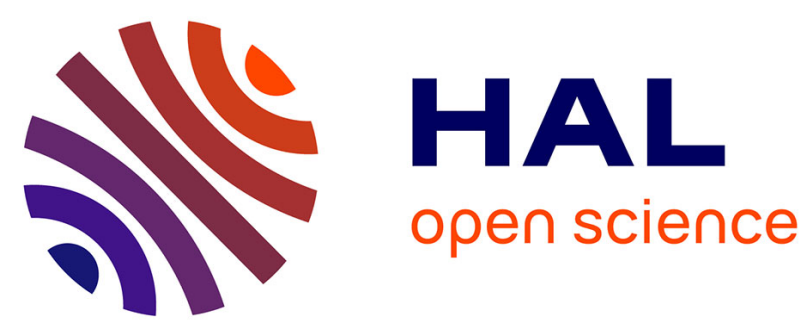

\title{
Aerosol distribution over the western Mediterranean basin during a Tramontane/Mistral event
}

T. Salameh, Philippe Drobinski, Laurent Menut, B. Bessagnet, Cyrille Flamant, A. Hodzic, R. Vautard

\section{- To cite this version:}

T. Salameh, Philippe Drobinski, Laurent Menut, B. Bessagnet, Cyrille Flamant, et al.. Aerosol distribution over the western Mediterranean basin during a Tramontane/Mistral event. Annales Geophysicae, 2007, 25 (11), pp.2271-2291. 10.5194/angeo-25-2271-2007 . hal-00227390

\section{HAL Id: hal-00227390 \\ https://hal.science/hal-00227390}

Submitted on 19 Dec 2015

HAL is a multi-disciplinary open access archive for the deposit and dissemination of scientific research documents, whether they are published or not. The documents may come from teaching and research institutions in France or abroad, or from public or private research centers.
L'archive ouverte pluridisciplinaire HAL, est destinée au dépôt et à la diffusion de documents scientifiques de niveau recherche, publiés ou non, émanant des établissements d'enseignement et de recherche français ou étrangers, des laboratoires publics ou privés. 


\title{
Aerosol distribution over the western Mediterranean basin during a Tramontane/Mistral event
}

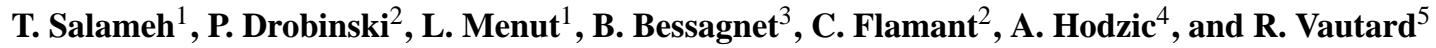 \\ ${ }^{1}$ Institut Pierre Simon Laplace/Laboratoire de Météorologie Dynamique, École Polytechnique/ENS/UPMC/CNRS, Palaiseau, \\ France \\ ${ }^{2}$ Institut Pierre Simon Laplace/Service d'Aéronomie, UPMC/UVSQ/CNRS, Paris, France \\ ${ }^{3}$ Institut National de l'Environnement Industriel et des Risques, INERIS, Verneuil en Halatte, France \\ ${ }^{4}$ National Center for Atmospheric Research, Boulder, CO, USA \\ ${ }^{5}$ Institut Pierre Simon Laplace/Laboratoire des Sciences du Climat et de l'Environnement, CEA/UVSQ/CNRS, Gif sur \\ Yvette, France
}

Received: 23 April 2007 - Revised: 4 October 2007 - Accepted: 18 October 2007 - Published: 29 November 2007

\begin{abstract}
This paper investigates experimentally and numerically the time evolution of the spatial distribution of aerosols over the Western Mediterranean basin during the 24 March 1998 Mistral event documented during the FETCH experiment. Mistral and Tramontane are very frequently northerly wind storms (5-15 days per month) accelerated along the Rhône and Aude valleys (France) that can transport natural and anthropogenic aerosols offshore as far as a few hundred kilometers, which can, in turn, have an impact on the radiation budget over the Mediterranean Sea and on precipitation.

The spatial distribution of aerosols was documented by means of the airborne lidar LEANDRE-2 and space-borne radiometer SeaWIFS, and a validated mesoscale chemical simulation using the chemistry-transport model CHIMERE with an aerosol module, forced by the non-hydrostatic model MM5.

This study shows that: (1) the Mistral and Tramontane contribute to the offshore exportation of a large amount of aerosols originally emitted over continental Europe (in particular, ammonium nitrate in the particulate phase and sulfates) and along the shore from the industrialized and urban areas of Fos-Berre/Marseille. The amount of aerosol loading solely due to the Mistral and Tramontane is as large as 34 times the background aerosol amount and the contribution of sea-salt particles to the total aerosol loading and optical depth ranges from 1 to $10 \%$ even in such stormy conditions; (2) the aerosol concentration pattern is very unsteady as a result of the time evolution of the two winds (or Genoa cy-
\end{abstract}

Correspondence to: T. Salameh

(tamara.salameh@1md.polytechnique.fr) clone position): The Tramontane wind prevails in the morning hours of 24 March, leaving room for the Mistral wind and an unusually strong Ligurian outflow in the afternoon. The Genoa surface low contributes to advect the aerosols along a cyclonic trajectory that skirts the North African coast and reaches Italy. The wakes trailing downstream the Massif Central and the Alps prevent any horizontal diffusion of the aerosols and can, at times, contribute to aerosol stagnation.

Keywords. Atmospheric composition and structure (Aerosols and particles; Pollution - urban and regional) - Meteorology and atmospheric dynamics (Mesoscale meteorology)

\section{Introduction}

The Mediterranean basin is featured by an almost-closed ocean basin surrounded by mountain ranges in which numerous rivers rise, a contrasted climate and vegetation from south to north, numerous and rapidly growing built-up areas along the coast with several major cities having industrial activities emitting a large number of gas substances and aerosols. Highly aerosol loaded air masses are found from the surface up to the upper troposphere and contribute to a decrease in air quality on a large scale and reduced precipitation in the region (Lelieveld et al., 2002). The aerosols found below 4-km height originate from regional sources, especially from western and eastern Europe (e.g. Sciare et al., 2003; Traub et al., 2003; Schneider et al., 2004), and from the Saharan desert (e.g. Bergametti et al., 1992; Moulin

Published by Copernicus Publications on behalf of the European Geosciences Union. 
et al., 1998; Guieu et al., 2002). Industrial activity, traffic, forest fires, agricultural and domestic burning are the main sources of pollution in Europe (e.g. Bergametti et al., 1992; Moulin et al., 1998; Lelieveld et al., 2002; Pace et al., 2005; Drobinski et al., 2007), whereas the close vicinity of the Saharan desert provides a source for considerable amounts of dust. Above 4-km height they are usually linked to transport due to global-scale motions and teleconnections, for instance, with the Indian monsoon and the North Atlantic Oscillation (Moulin et al., 1997).

Aerosols are harmful for ecosystems and human health, and they affect the Mediterranean climate and water cycle. Indeed, they affect the atmospheric energy budget by scattering and absorbing solar radiation, and contribute to the suppression of evaporation and moisture transport, in particular to North Africa and the Middle East (Lelieveld et al., 2002). The absorption of solar radiation by aerosol particles (from anthropogenic and biomass origin) can cause a positive radiative forcing in the atmosphere and considerably modify atmospheric the stability. As reported by Pace et al. (2005) and Hodzic et al. (2007), aerosol radiative forcing was estimated up to $25 \mathrm{~W} \mathrm{~m}^{-2}$ over the Mediterranean basin during the August 2003 heat-wave episode. Aerosols also affect the Mediterranean biogeochemistry by deposition of dissolved inorganic phosphorus (Bergametti et al., 1992; Bartoli et al., 2005), silicon (Bartoli et al., 2005) and iron (Guieu et al., 2002) from soil-derived dust from the desert areas of North Africa and anthropogenic emissions from European countries. These are internal sources of nutrients and constitute an important pathway for nutrients to the photic zone of the Mediterranean Sea (Migon et al., 1989; Béthoux, 1989; Bergametti et al., 1992; Prospero et al., 1996; Guerzoni et al., 1999; Benitez-Nelson 2000; Béthoux et al., 2002). In the context of climate change, in which the Mediterranean basin appears quite vulnerable due to hydric stress and ever increasing pollution levels, it is thus crucial that knowledge be improved concerning the mechanisms linking the dynamics of the main flow regimes and the existing pollution sources scattered around the basin, in order to provide insight into future trends at the regional scale.

The western Mediterranean climate is frequently affected by the Mistral and its companion wind, the Tramontane (Georgelin and Richard, 1996; Drobinski et al., 2001). The Mistral is a severe northerly wind that develops along the Rhône valley between the Massif Central and the Alps (while the Tramontane blows in the Aude valley between the Pyrénées and the Massif Central) (Fig. 1), and occurs between 5 and 15 days per month. The development of the Mistral is preconditioned by a cyclogenesis over the Gulf of Genoa, the passage of a trough through France and high pressures over Spain and southern France which bring a northerly/north-westerly flow over the western Mediterranean. The Mistral occurs all year long but exhibits a seasonal variability either in terms of its strength and direction, or in terms of its spatial distribution (Mayençon, 1982;
Orieux and Pouget, 1984). At the regional scale, the Mistral is frequently observed to extend as far as a few hundred kilometers from the coast (Jansá, 1987) and is thus associated with low continental pollution levels near the coastline as it advects the pollutants away from their sources of emission over the Mediterranean Sea (Bastin et al., 2006; Drobinski et al., 2007).

Due to favourable dispersion conditions, air quality studies generally do not focus on Mistral events. The FETCH (Flux, Etat de mer et Teledetection en Condition de fetcH variable) experiment (Hauser et al., 2003) offers an ideal framework to investigate the transport and resulting concentration distribution of aerosols over the Mediterranean Sea during the dominant wind regime associated with Mistral and Tramontane. The FETCH experiment took place from 12 March to 15 April 1998 and was dedicated to improve the knowledge of the interactions between the ocean and the atmosphere in a coastal environment under strong wind conditions. The 24 March $1998 \mathrm{Mistral} /$ Tramontane case is a strong episode, typical of intermediate season Mistral events compared to weaker summer Mistral events (e.g. Drobinski et al., 2005; Bastin et al., 2006). Flamant (2003) analyzed the complex structure of the atmospheric boundary layer (ABL) observed using an airborne lidar over the Gulf of Lion during the 24 March 1998 Mistral event (see Fig. 1). Even though the study by Flamant (2003) suggested that the existence of a marked east-west aerosol concentration gradient offshore is related to larger concentrations of pollution aerosol from the city of Marseille and the industrial petrochemical complex of Fos/Berre, the highly spatially resolved aerosol measurements needed to (un)validate this hypothesis simply did not exist. By combining in-situ, passive (radiometer and photometer) and active (lidar) remote sensing observations (on ground, sea-borne, airborne and satellite-borne) and numerical simulations from the MM5 mesoscale model and the chemistry transport model CHIMERE), we better address this question in the present article. Therefore, this article is designed to analyze:

- the relation between the dynamic processes driving the small-scale structure of the Mistral flow and the aerosol distribution observed by the airborne lidar and the satellite imagery,

- the amount of aerosol mass transported by the Mistral and Tramontane in addition to the background aerosol mass,

- the aerosol sources, composition and distribution over the whole western Mediterranean basin, especially the sea-salts which can have a significant contribution under strong wind conditions.

The instrument set-up (i.e. FETCH-related sea-borne, airborne and space-borne observations) and the numerical models used in this study are described in Sect. 2. In Sect. 3, the 


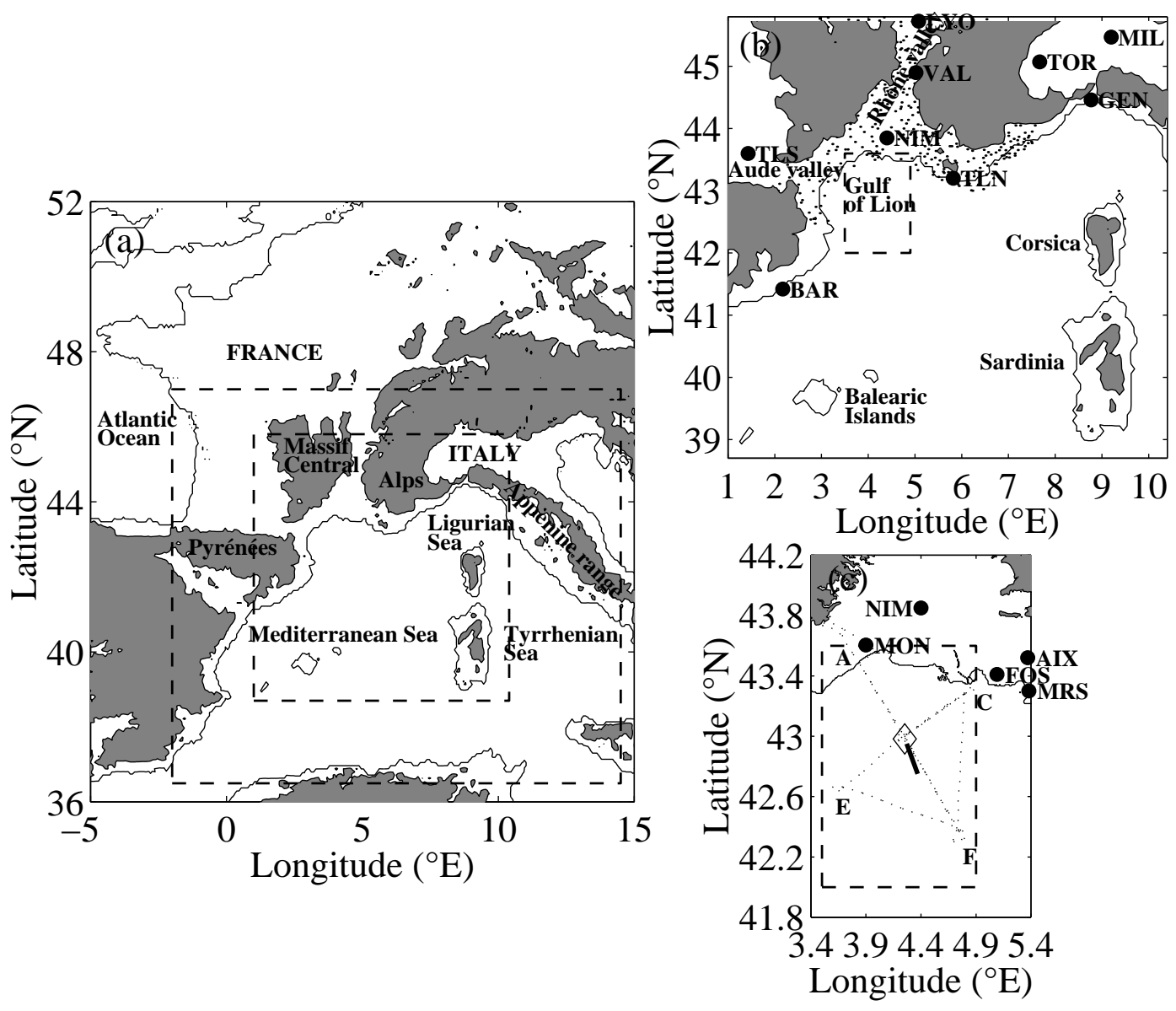

Fig. 1. Panel (a): Map of France with the topography shaded in grey when higher than $500 \mathrm{~m}$ above sea level. The two rectangles depicted via a dashed line, display the large and medium domains (hereafter called domain 1 and domain 2, respectively) of the MM5 simulations. Panel (b): Domain 2 of the MM5 simulation with its nested smaller domain (hereafter called domain 3) in the rectangle. The acronyms BAR, GEN, MIL, NIM, LYO, TLN, TLS, TOR and VAL stand for the city names Barcelona, Genoa, Milano, Nîmes, Lyon, Toulon, Toulouse, Torino and Valence, respectively. The dots indicate the locations of the operational meteorological surface stations. Panel (c): Zoom on the Gulf du Lyon area. The rectangle displays the small domain (domain 3) of the MM5 simulations. The dotted line corresponds to the flight track of the ARAT carrying the water vapor lidar LEANDRE-2 on 24 March 1998 in the afternoon and the thick solid line corresponds to the route of R/V ATALANTE. The diamond marker shows the location of the ASIS buoy. The acronyms AIX, FOS, MON, MRS and NIM correspond to the city names Aix en Provence, Fos/Berre, Montpellier, Marseille and Nîmes, respectively.

meteorological environment leading to the Mistral episode is analyzed, as well as the fine-scale structure of the Mistral flow. In Sect. 4, the aerosol distribution over the western Mediterranean basin is discussed, before conclusions are drawn in Sect. 5.

\section{Numerical models and measurements}

\subsection{Numerical models}

\subsubsection{Dynamical model}

The dynamical numerical simulations presented in this study have been conducted using the fifth generation Penn State
University-National Center for Atmospheric Research MM5 model, version 3.6 (Dudhia, 1993; Grell et al., 1995). The model solves the non-hydrostatic equations of motion in a terrain following sigma coordinates. Three interactively nested model domains are used, the horizontal mesh size being $27 \mathrm{~km}, 9 \mathrm{~km}$ and $3 \mathrm{~km}$, respectively. Domains 1 (coarse domain), 2 (medium domain) and 3 (fine domain) are centered around $43.7^{\circ} \mathrm{N}, 4.6^{\circ} \mathrm{E}$ and cover an area of $1350 \mathrm{~km} \times 1350 \mathrm{~km}, 738 \mathrm{~km} \times 738 \mathrm{~km}$ and $120 \mathrm{~km} \times 174 \mathrm{~km}$, respectively (see Fig. 1). Domain 1 covers half of France and the western Mediterranean Sea. Domain 2 covers the Rhône valley, the western Alps, the Massif Central, Corsica and Sardinia. Domain 3 covers the Rhône valley delta. The model orography of the three domains is interpolated from terrain data with $30^{\prime \prime}$ resolution. It is filtered by a two-pass 
smoother-desmoother (Guo and Chen, 1994), in order to remove two-grid interval waves that would induce numerical noise. Information on land use was obtained from USGS (United States Geological Survey) data with the same horizontal resolution as for orography. In the vertical, 43 unevenly spaced full sigma-levels are used, corresponding to 42 half-sigma levels where most of the variables are computed. The lowermost half-sigma level $(\sigma=0.999)$ is about $12 \mathrm{~m}$ above ground. The vertical distance between the model levels is about $50 \mathrm{~m}$ close to the ground and increases up to $1200 \mathrm{~m}$ near the upper boundary which is located at $100 \mathrm{hPa}$.

A complete set of physics parameterizations is used. Cloud microphysics is treated with a sophisticated scheme having prognostic equations for cloud water, cloud ice, cloud ice particle number concentration, rain, snow and graupel (Reisner et al., 1998), using modifications proposed by Chiriaco et al. (2006). The Grell cumulus parametrization (Grell, 1993) is used in model domains 1 and 2. In model domain 3, a cumulus parametrization is not needed because convection is resolved explicitly at such high resolution. The radiation scheme accounts for the interaction with moisture and clouds (Grell et al., 1995; Mlawer et al., 1997). The ABL is parameterized using the Hong and Pan scheme (Hong and Pan, 1996). It is an efficient scheme based on the Troen and Marht (1986) representation of the countergradient term and eddy viscosity profile in the well mixed ABL, and is suitable for high resolution in the ABL.

The initial and boundary conditions are taken from the ECMWF (European Centre for Medium Range Weather Forecast) reanalyses ERA-40. These reanalysis data are available every six hours on a $1^{\circ} \times 1^{\circ}$ latitude-longitude grid. In order for the synoptic flow to stay close to the meteorological analyzes, the meteorological simulation uses nudging for all variables with a coefficient of $10^{-4} \mathrm{~s}^{-1}$. The initialization date is 20 March 1998 at 12:00 UTC and the simulation ends on 25 March 1998 at 18:00 UTC, with a re-initialization on 23 March 1998 at 12:00 UTC (the MM5 run between 20 and 23 March is used for aerosol-related spin-up needs; see Sect. 2.1.2).

In the following, MM5 simulations are used to provide the three-dimensional environment necessary for the interpretation of the measurements, and these simulations are also the meteorological forcing for the regional chemistry-transport model CHIMERE.

\subsubsection{Chemistry-transport model}

The chemistry-transport model forced by the MM5 meteorology is CHIMERE. It is a 3-D chemistry-transport model, developed cooperatively by the French Institut PierreSimon Laplace (IPSL), Laboratoire Interuniversitaire des Systèmes Atmosphériques (LISA) and Institut National de l'Environnement industriel et des RISques (INERIS). CHIMERE is a 3-D chemistry transport model that simulates gas-phase and aerosol-phase chemistry and its trans- port at the scale of the continent (Schmidt et al., 2001) or at the regional scale (Vautard et al., 2001, 2003). It simulates the concentration of 44 gaseous species and 6 aerosol chemical compounds. Sea salt is accounted for in our simulations (Monahan et al. 1986). In the CHIMERE aerosol version (Bessagnet et al., 2004; Hodzic et al., 2004), the population of aerosol particles is represented using a sectional formulation, assuming discrete aerosol size sections and considering the particles of a given section as homogeneous in composition (internally mixed). As in the work of Bessagnet et al. (2004), we use six diameter bins ranging between $10 \mathrm{~nm}$ and $40 \mu \mathrm{m}$, with a geometric increase in bin bounds. The aerosol module accounts for both inorganic and organic species, of primary or secondary origin, such as primary particulate matter (PPM), sulfates, nitrates, ammonium, secondary organic species (SOA) and water. PPM is composed of primary anthropogenic species, such as elemental and organic carbon and crustal materials. In the model, ammonia, nitrate, and sulfate are considered in aqueous, gaseous, and particulate phases.

In the present application, the model domains match the MM5 domains with a vertical resolution of 12 sigmapressure levels extending up to $500 \mathrm{hPa}$ that covers the ABL and the lower part of the free troposphere. The meteorological variables used as input are wind, temperature, mixing ratio for water vapor and liquid water in clouds, 2$\mathrm{m}$ temperature, surface heat and moisture fluxes and precipitation. Boundary conditions of CHIMERE simulations are taken from climatologies of the LMDZ-INCA chemistry transport model for the gazeous species, and from the GOCART (The Georgia Tech/Goddard Global Ozone Chemistry Aerosol Radiation Transport) aerosol forecasting model for the aerosols. Emissions of primary particulate matter $\mathrm{PM}_{10}$ and $\mathrm{PM}_{2.5}$ (particulate matter of diameter less than $10 \mu \mathrm{m}$ and $2.5 \mu \mathrm{m}$ ) and the anthropogenic emissions for $\mathrm{NO}_{\mathrm{x}}, \mathrm{CO}$, $\mathrm{SO}_{2}$, NMVOC (Non Methane Volatile Organic Compounds) and $\mathrm{NH} 3$ gas-phase species for 10 anthropogenic activity sectors (as defined by the SNAP categories) are provided by EMEP (available at http://www.emep.int) with spatial resolution of $50 \mathrm{~km}$ (Vestreng, 2003). There is no online coupling between MM5 and CHIMERE, so the radiative effect of the aerosol and gas simulated with CHIMERE does not modify the atmospheric dynamics simulated with MM5. The CHIMERE simulation covers the same period as the MM5 simulation.

\subsection{Observations}

Over the continent, we mainly use the measurements from the operational radiosoundings and synoptic meteorological stations of Météo-France. On 24 March 1998, operational radiosondes were released every twelve hours from Lyon and Nîmes. At the surface, the operational meteorological surface station network of Météo France gave access to the surface thermodynamical fields (precipitation, wind speed and 
direction, temperature, humidity, pressure). The locations of the operational meteorological surface stations used in this study are shown in Fig. 1b.

Over the Mediterranean Sea, we use the measurements of meteorological variables collected on board the research vessel (R/V) Atalante, the ASIS (Air-Sea Interaction Spar) buoy and the Avion de Recherche Atmosphérique et Télédétection (ARAT), as well as from satellites (the Sea-viewing Wide Field-of-view Sensor-SeaWIFS- and the Active Microwave Instrumentation-Wind Scatterometer AMI/Wind on board the European Remote Sensing Satellite ERS). The complementarity of the data provided by these various instruments is an essential aspect of this study. The locations of the measurement sites used in this study are shown in Fig. 1.

The R/V Atalante had balloon launching capability and carried an instrumented mast for mean and turbulent measurements at a height of $17 \mathrm{~m}$ above the sea surface. The ASIS buoy made measurements of mean and turbulent atmospheric variables $7 \mathrm{~m}$ above the sea at $43^{\circ} / 4.25^{\circ} \mathrm{E}$. The ARAT aircraft was equipped with standard in-situ sensors and embarked the differential absorption lidar LEANDRE2. The ARAT afternoon mission on 24 March 1998 (between 16:20 and 18:50 UTC) was designed in such a manner that long levelled legs were flown along and across the mean ABL wind direction. The structure of the flow and its evolution with time has been analyzed using high resolution measurements $(15 \mathrm{~m}$ in the vertical and $160 \mathrm{~m}$ in the horizontal) of atmospheric reflectivity at $730 \mathrm{~nm}$, made with the airborne lidar LEANDRE-2. Because it is sensitive to relative humidity, as well as aerosol properties and concentration, lidar-derived reflectivity is extremely useful to investigate ABL structural properties. Here we shall discuss reflectivity measurements made with a nadir pointing system from an altitude of $4 \mathrm{~km}$ above mean sea level (m.s.l.).

The high spatial and temporal documentation of the $150 \mathrm{~km} \times 200 \mathrm{~km}$ FETCH target area (i.e. Gulf of Lion) allows for a very detailed insight on the dynamics of the Mistral event as well as on the aerosol distribution. However, this data set was complemented by satellite data from the AMIWind/ERS scatterometer, providing daily mean surface wind speed and wind stress over the whole Mediterranean Sea at $1^{\circ}$ resolution, and from SeaWIFS providing the aerosol optical depth at $865 \mathrm{~nm}$ while passing over the western Mediterranean at 11:32 UTC.

\section{The 24 March 1998 Mistral event}

\subsection{Synoptic environment}

The 24 March 1998 Mistral event was featured by the existence of an upper level trough associated with a cold front progressing toward the Alps and a shallow vortex (1014 hPa) over the Tyrrhenian Sea between Sardinia and continental Italy, at 06:00 UTC. As the day progressed, the low over the Tyrrhenian deepened (from 1014 to $1008 \mathrm{hPa}$ between 06:00 and 15:00 UTC) while remaining relatively still. After 15:00 UTC, the low continued to deepen (from 1008 to $1002 \mathrm{hPa}$ ) while moving to the southeast. It was located over Sicily on 25 March 1998 at 06:00 UTC. The high pressure system over Spain and southern France did not evolve much with time and remained at values around $1022 \mathrm{hPa}$.

The multistage evolution of the Alpine lee cyclone over the Tyrrhenian Sea induced a very non-stationary wind regime over the Gulf of Lion (see also Flamant, 2003). The diurnal evolution of the Mistral and the Tramontane on 24 March 1998 are evidenced on the wind field simulated in the $\mathrm{ABL}($ at $950 \mathrm{hPa}$ ) by the MM5 model at 06:00, 09:00, 12:00, 15:00, 18:00 and 21:00 UTC (Fig. 2). In the early stage (low at 1014 hPa, 06:00 UTC), the Tramontane flow prevailed over the Gulf of Lion due to the high position (in terms of latitude) of the depression. The Mistral extended all the way to Southern Corsica, wrapping around the depression. To the north, a weak easterly outflow was observed over the Gulf of Genoa. As the low deepened $(1010 \mathrm{hPa})$, the prevailing wind regime shifted to a well-established Mistral, peaking around 12:00 UTC. The Mistral was observed to reach Southern Sardinia where it wrapped around the depression. At this time, the outflow from the Ligurian Sea (i.e. Gulf of Genoa) had become stronger. In the afternoon, the Mistral was progressively disrupted by the strengthening outflow coming from the Ligurian Sea, in response to the deepening low over the Tyrrhenian Sea (1008 hPa, 15:00 UTC) and the channelling induced by the presence of the Apennine range (Italy) and the Alps. In the evening, the Mistral was again well established over the Gulf of Lion as the depression continued to deepen (1002 $\mathrm{hPa}, 21: 00 \mathrm{UTC})$, but moved to the southeast, reducing the influence of outflow from the Ligurian Sea on the flow over the Gulf of Lion. During this period, the Tramontane flow appeared to be much steadier than the Mistral and less disrupted by the return flow associated with the depression.

This complex evolution of the flow affects directly the aerosol distribution over the western Mediterranean.

\subsection{Structure of the Mistral over the continent}

The radiosoundings launched from Lyon on 24 March 1998 at 00:00 and 12:00 UTC show the synoptic northwesterly flow blowing above $1 \mathrm{~km}$ a.s.l. (Fig. 3, top row). Below 1 $\mathrm{km}$ height, a low-level jet blows at about $5-8 \mathrm{~m} \mathrm{~s}^{-1}$ from the north and is aligned with the Rhône valley axis displaying channelling in the valley (see, in particular, 00:00 UTC profiles). Between 1 and $3 \mathrm{~km}$ a.s.l., the wind direction veers to the northeast and the wind speed increases from about $5 \mathrm{~m} \mathrm{~s}^{-1}$ to about $15 \mathrm{~m} \mathrm{~s}^{-1}$ at $3 \mathrm{~km}$ a.s.l. (see, in particular, 12:00 UTC profiles). The Mistral jet blows within the ABL (below $1 \mathrm{~km}$ ). The radiosoundings launched from Nîmes (Fig. 3, middle row) show that the Mistral experiences channelling in the Rhône Valley and accelerates with 

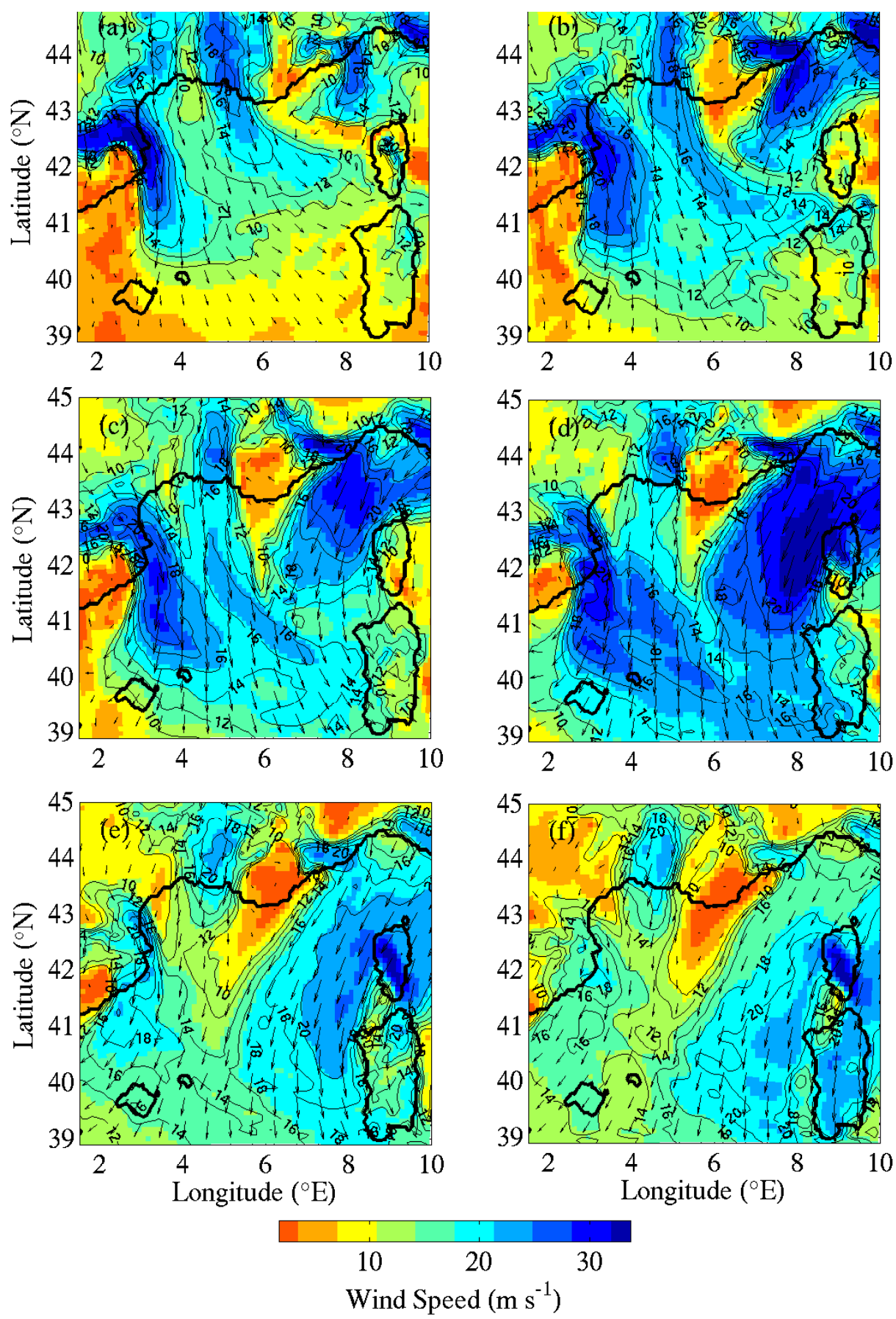

Fig. 2. Horizontal wind fields simulated with MM5 (at 950 hPa) and extracted from domain 2 on 24 March 1998 at 06:00 (a), 09:00 (b), 12:00 (c), 15:00 (d), 18:00 (e) and 21:00 UTC (f), respectively. The isocontours represent the isotachs. Contour interval is $2 \mathrm{~m} \mathrm{~s}^{-1}$ from 10 to $20 \mathrm{~m} \mathrm{~s}^{-1}$. The black solid line represents the coastline.

the wind speed increasing from $5-8 \mathrm{~m} \mathrm{~s}^{-1}$ in Lyon to $15-$ $18 \mathrm{~m} \mathrm{~s}^{-1}$ in Nîmes. The MM5 model (solid line) reproduces the vertical profiles of wind speed and direction, and potential temperature with a $2 \mathrm{~m} \mathrm{~s}^{-1}$ difference, less than $20^{\circ}$ and $2 \mathrm{~K}$, on average, respectively (the wind speed difference can reach at most $5 \mathrm{~m} \mathrm{~s}^{-1}$ at 11:00 UTC on the R/V
Atalante). Except for the near-surface temperature, the radiosoundings launched from Lyon and Nîmes on 24 March 1998 at 00:00 and 12:00 UTC show that the Mistral characteristics are fairly persistent with time.

The simulated surface wind and temperature fields are evaluated by comparing the measured $10-\mathrm{m}$ horizontal wind 

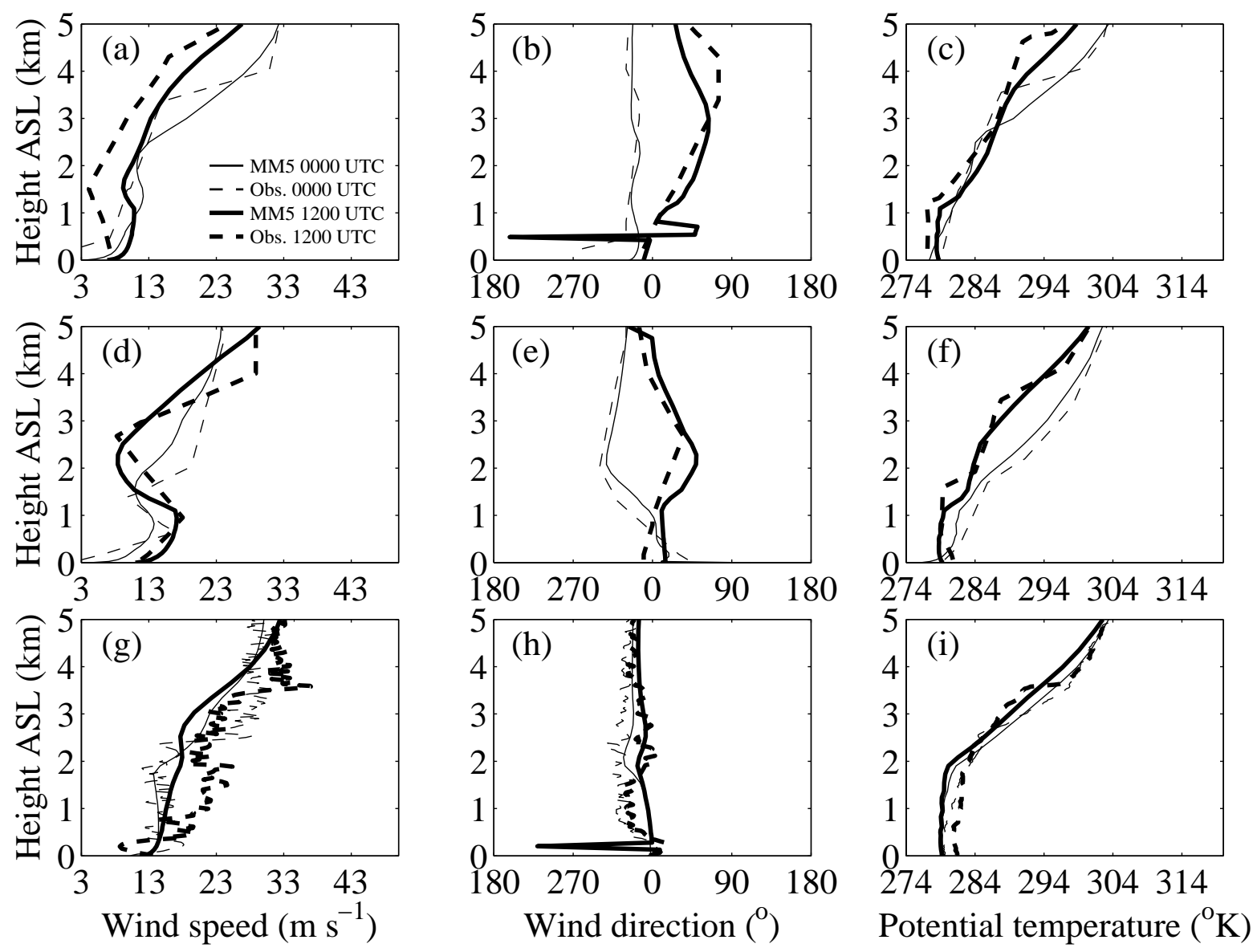

Fig. 3. Vertical profiles of wind speed, wind direction and potential temperature (left, middle and right columns, respectively) over Lyon, Nîmes and on the location of the R/V ATALANTE (top, middle and bottom rows, respectively). The measured and simulated profiles are displayed with dashed and solid lines, respectively. On the first and the second rows, thin lines represent measurements at 00:00 UTC and bold lines represent measurements at 12:00 UTC. On the third row, thin lines are for measurements at 09:00 UTC and bold lines are for measurements at 11:00 UTC. The location of the R/V ATALANTE was 42.75 $\mathrm{N} / 4.37^{\circ} \mathrm{E}$ at 09:00 $\mathrm{UTC}$ and $42.95^{\circ} \mathrm{N} / 4.27^{\circ} \mathrm{E}$ at $11: 00 \mathrm{UTC}$.

components and 2-m temperature to their simulated counterparts interpolated at the location of the meteorological surface stations in southern France (see dots in Fig. 1b). Quantitatively, Fig. 4 shows the histograms of the difference between the three-hourly simulated and measured 10-m zonal and meridional wind components and 2-m temperature during the $24 \mathrm{~h}$ on 24 March 1998. The measured 10-m wind speed and 2-m temperature accuracies are $1 \mathrm{~m} \mathrm{~s}^{-1}$ and about $0.1^{\circ} \mathrm{K}$, respectively. The biases between MM5 and the measured wind components are about $-1 \mathrm{~ms}^{-1}$ for the zonal component and close to zero for the meridian component, which are thus non significant. The standard deviation is also small considering the accuracy of the wind observations. As for the temperature, the largest discrepancies are found in the steep orography regions, where the height of the topography is not accurately represented in the model and at night when numerical diffusion slightly deteriorates the simulation of the near-surface temperature and the katabatic flows.

\subsection{Structure of the Mistral over the Mediterranean Sea}

Over the Mediterranean Sea, the data are generally sparse, and available from satellite-borne sensors, thus restricted to the surface and reliable few hundred kilometers away from the shore. Figure 5 shows the daily mean values of the sea surface wind speed provided by the satellite-borne AMIWind/ERS scatterometer over the Mediterranean Sea at $1^{\circ}$ resolution (no wind vectors are available for year 1998). It shows three regions of sea surface wind speed exceeding $20 \mathrm{~m} \mathrm{~s}^{-1}$ : to the west, the Tramontane merge with the Spanish Cierzo; at around $7^{\circ} \mathrm{E}$ longitude, the Mistral blows around the Genoa cyclone and immediately to the east of Sicily and Sardinia, the Ligurian outflow. The MM5 models reproduce the same structure but with lower wind speed, which can reach $5 \mathrm{~m} \mathrm{~s}^{-1}$ in the regions of strong flows. This can be attributed to the fact that the largest AMI-Wind/ERS errors are found near the shore. The ASIS buoy data allows 

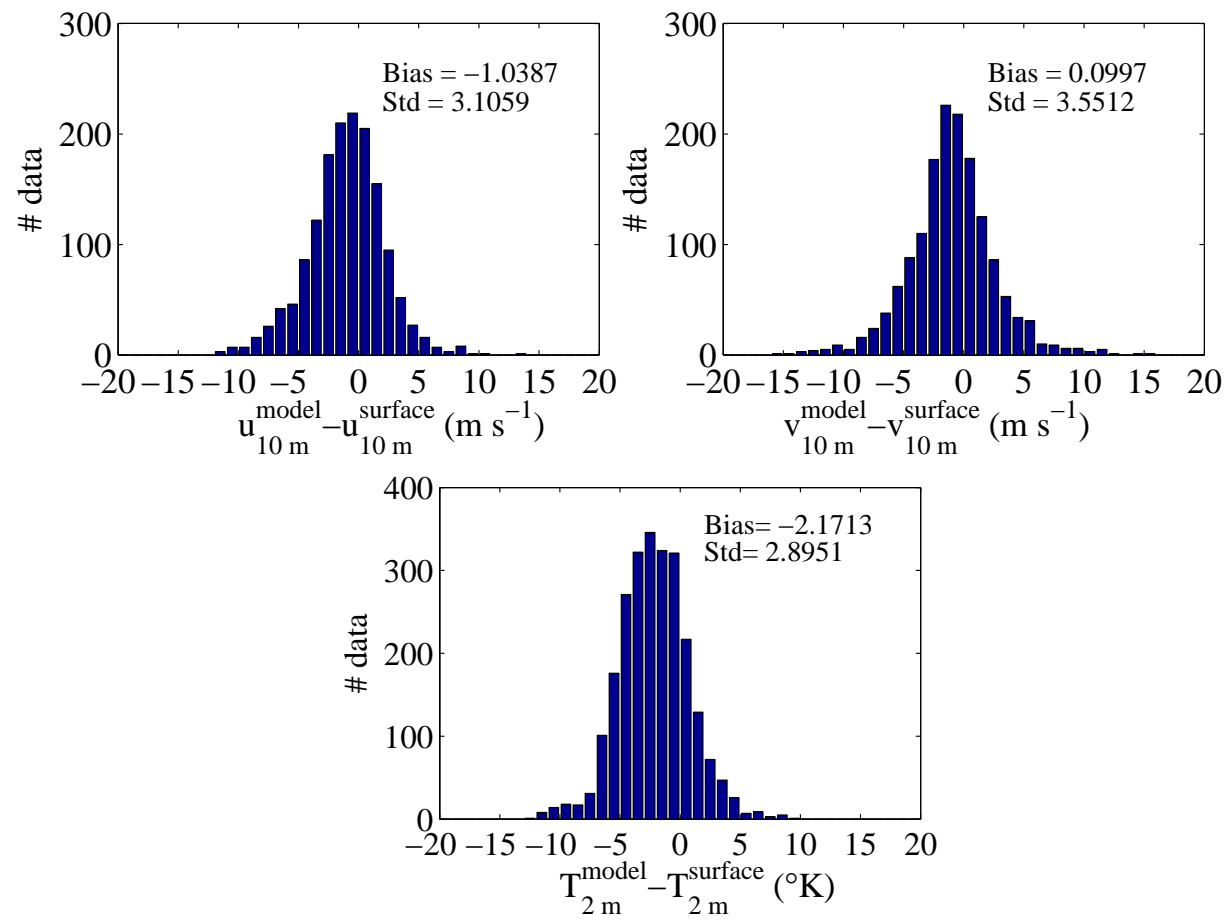

Fig. 4. Histograms of the difference between the three-hourly simulated and measured 10-m zonal (a) and meridional (b) wind components and 2-m temperature (c) during the $24 \mathrm{~h}$ period of 24 March 1998 in southern France (see dots in Fig. 1b). The measured 10-m wind speed and 2-m temperature accuracies are $1 \mathrm{~m} \mathrm{~s}^{-1}$ and about $0.1^{\circ} \mathrm{K}$, respectively.
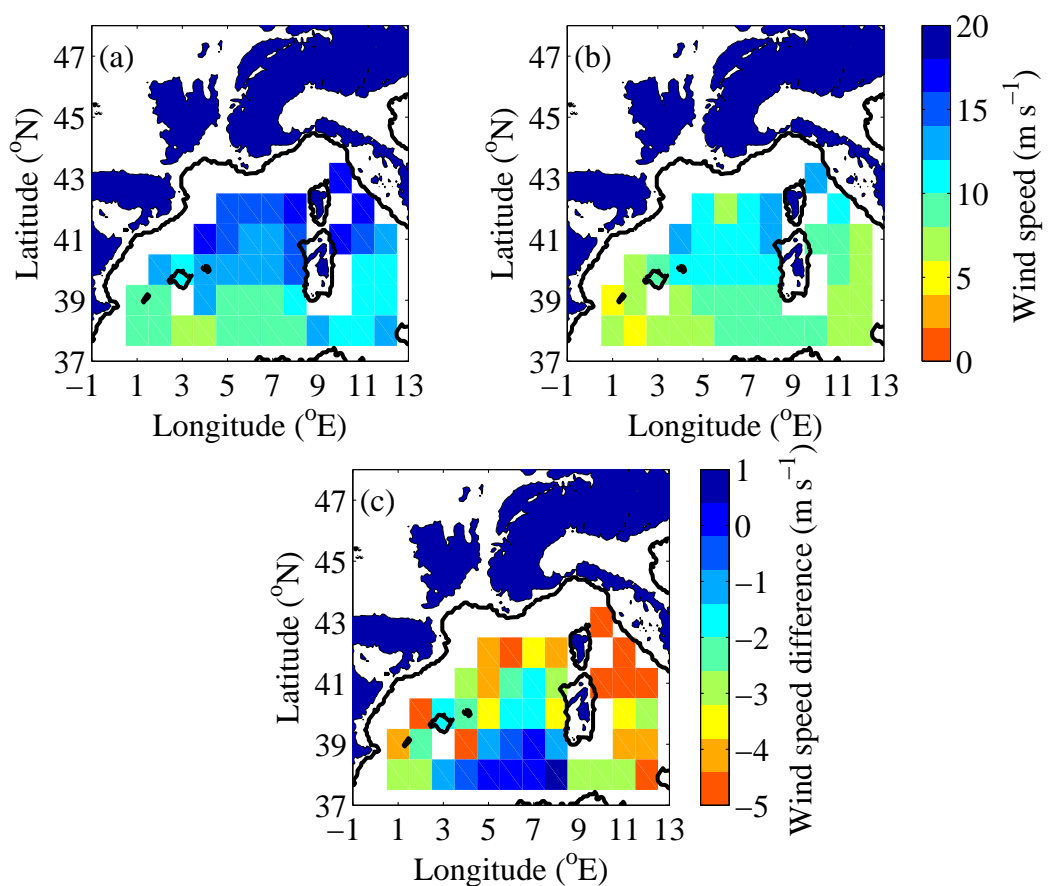

Fig. 5. (a), (b) and (c) are the daily mean values of the wind speeds measured on 24 March 1998 by the AMI-Wind/ERS satellite over the sea surface, simulated by MM5 (domain 3) and the difference between the measured and simulated wind speeds, respectively. (a) and (b) are with the same color scale. 
for a more detailed comparison at a single point. Figure 6 shows the good agreement between the ASIS buoy measurements and MM5 simulations of surface wind speed and direction, temperature, relative humidity and surface stress (better than $2 \mathrm{~m} \mathrm{~s}^{-1}, 10^{\circ}, 1^{\circ} \mathrm{C}, 20 \%$ and $0.1 \mathrm{~N} \mathrm{~m}^{-2}$, respectively, with some intermittent exceptions). This figure illustrates the unsteady aspect of the Mistral/Tramontane episode with the Tramontane blowing over the buoy between 04:00 and 08:00 UTC, followed by a calm period until the Mistral breaks through after 12:00 UTC.

The radiosoundings launched at 09:00 UTC and 11:00 UTC from the R/V Atalante at $\left(42.75^{\circ} \mathrm{N} ; 4.37^{\circ} \mathrm{E}\right)$ and $\left(42.95^{\circ} \mathrm{N} ; 4.27^{\circ} \mathrm{E}\right)$, respectively, show a northerly wind flow up to $5 \mathrm{~km}$ and more (Fig. $3 \mathrm{~g}$, h and i). The vertical profiles of potential temperature at 09:00 and 11:00 UTC show a remarkable persistence of the thermodynamical characteristics of the Mistral, with a potential temperature inversion at about $2-\mathrm{km}$ height which corresponds to the ABL depth. At 09:00 UTC, the wind blows at approximately $15 \mathrm{~m} \mathrm{~s}^{-1}$ within the ABL and increases up to $28 \mathrm{~m} \mathrm{~s}^{-1}$ above (Fig. 3g). The wind speed is stronger at 11:00 UTC than at 09:00 UTC $\left(20-22 \mathrm{~m} \mathrm{~s}^{-1}\right.$ below $\left.3 \mathrm{~km}\right)$, since the $\mathrm{R} / \mathrm{V}$ Atalante moves closer to the Mistral core. The MM5 model reproduces the vertical profiles of windspeed and direction, and potential temperature with at most a $2 \mathrm{~m} \mathrm{~s}^{-1}$ (09:00 UTC) to $5 \mathrm{~m} \mathrm{~s}^{-1}$ (11:00 UTC) difference and less than $30^{\circ}$ and $2 \mathrm{~K}$, on average, for the wind speed and direction and potential temperature, respectively.

\section{Aerosol distribution at the scale of the western Mediterranean basin}

\subsection{Sources of atmospheric pollutants}

The western Mediterranean basin is characterized by a meridional gradient of surface land types, mainly associated with vegetation and aerosol sources. South of the basin, the desert is a primary source of mineral dust. West and north of the basin, some aerosol sources are large industrial zones (refineries, power plants,...) surrounded by residential areas with important traffic, such as Barcelona, Marseille, Lyon, Milano and Rome. Rural areas prone to agriculture or covered by Mediterranean natural landscape are the main sources of biogenic emissions. Emissions related to ship traffic also impact Mediterranean pollution levels and climate (Marmer and Langmann, 2005). Finally, under stormy condition, the sea salts may not be negligible in the aerosol loading over the Mediterranean Sea and may also affect the radiative budget (e.g. Collins et al., 2002, for the Indian Ocean).

Some anthropogenic species, such as nitrogen oxides (Fig. 7a), are mainly emitted via traffic, industries and domestic combustion. For instance, over the continent, maxima of NO emissions are seen in the main cities Toulouse, Lyon, Marseille, Toulon, as well as Milano. Over the sea,
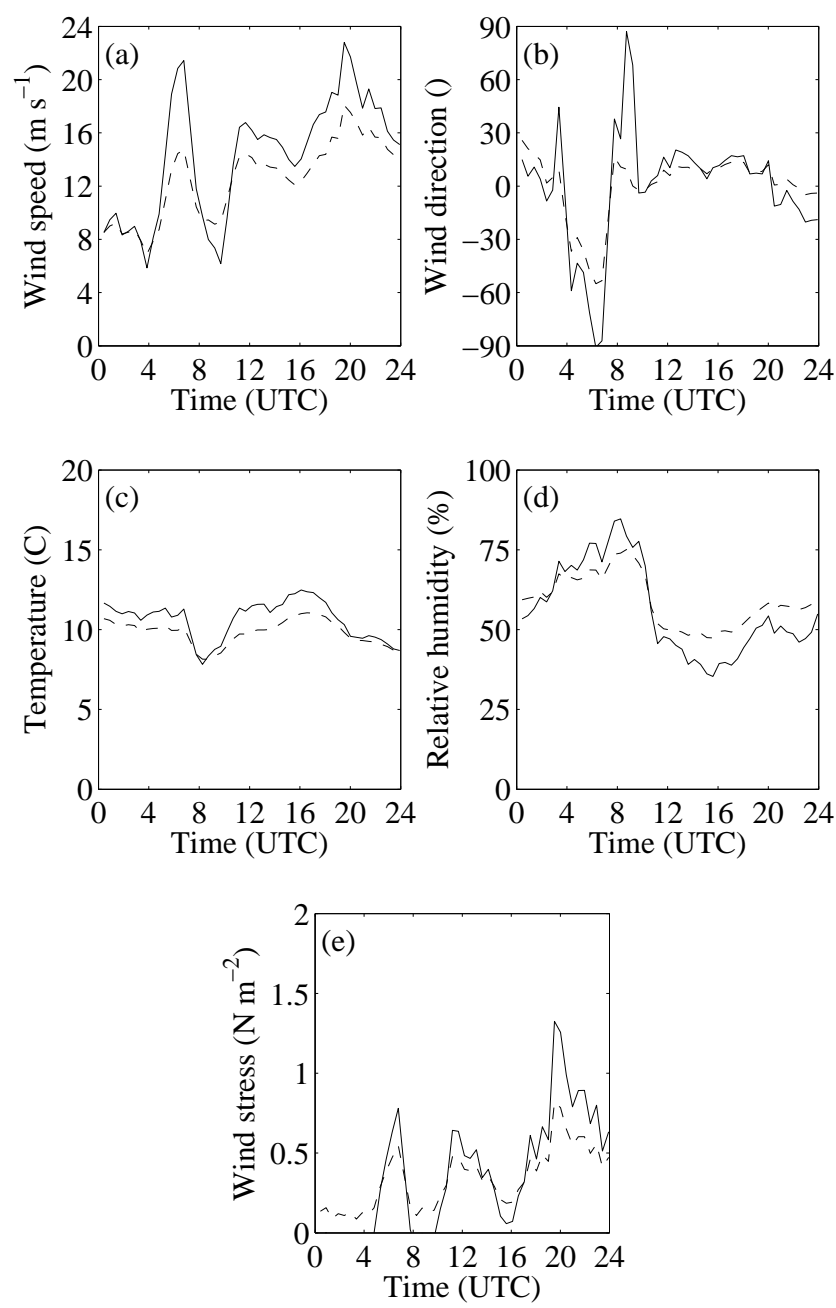

Fig. 6. Surface wind speed (a) and direction (b), temperature (c), relative humidity (d) and surface stress (e) as a function of time from the ASIS buoy measurements (dashed line) (see diamond in Fig. 1c) and from the MM5 simulations (solid line).

evidence of emissions associated with maritime traffic is also seen along the northern African coastline (i.e. ship routes between Gibraltar and the Suez canal), as well as along the Spanish coastline between Marseille and Gibraltar or along the Thyrrennean coast. $\mathrm{SO}_{2}$ (Fig. 7c) is mainly emitted via industrial activities and domestic combustion, as shown by the more scattered emission pattern. The emissions associated with maritime traffic are significant. $\mathrm{CO}$ and coarse primary particulate matter (PPM, of size less than $10 \mu \mathrm{m}$ and more than $2.5 \mu \mathrm{m}$ ) emissions are shared by traffic and various sources of combustion. These sources are significant in the main western Mediterranean cities, as shown in Fig. 7 (b and d). 

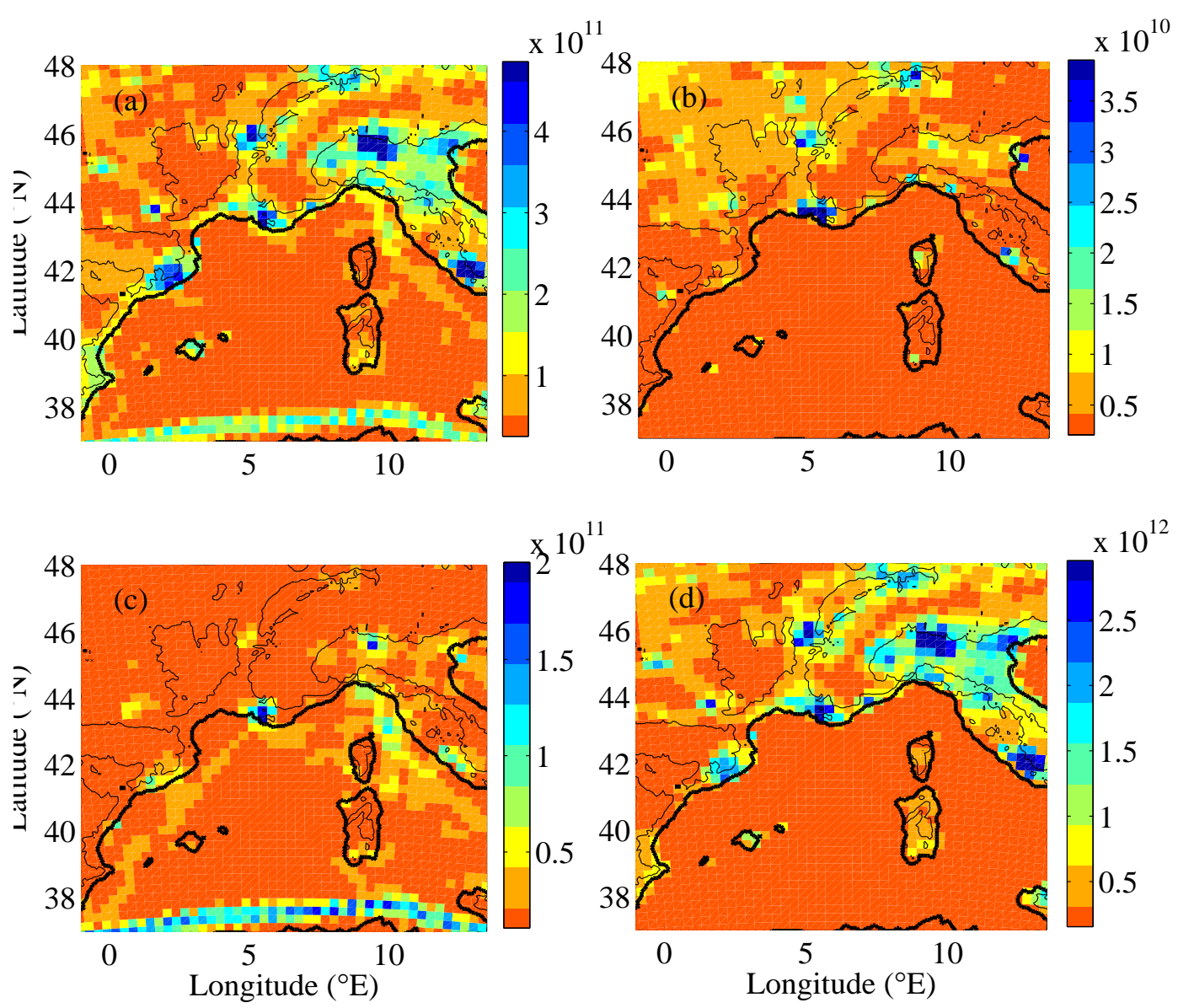

Fig. 7. EMEP inventory emissions in $\mathrm{Mg} /(50 \mathrm{~km} \times 50 \mathrm{~km}) / \mathrm{year}$, adjusted on the grid of the domain 3 at 12:00 UTC. Panels (a), (b), (c) and (d) represent the concentrations of NO (a), PPM coarse particles $(\geq 2.5 \mu \mathrm{m}$ and $\leq 10 \mu \mathrm{m})(\mathrm{b}), \mathrm{SO}_{2}$ (c) and CO (d) during a labor day of March 1998.

\subsection{Analysis at the scale of the Gulf of Lion}

On the shore of the Gulf of Lion, the area around the city of Marseille and the Berre pond, in southeastern France, is a source region of large urban and industrial emission, with a high occurrence of photochemical pollution events (Drobinski et al., 2007). The aerosol optical depth (AOD) at $865 \mathrm{~nm}$, derived from the SeaWIFS pass over the Gulf of Lion at 11:32 UTC on 24 March 1998 (obtained from the SeaDAS software), is shown in Fig. 8c. Figure 8 evidences that most of the western Mediterranean was covered by clouds (white area; the MM5 cloud cover was very similar to the SeaWIFS observations, not shown), with the notable exception of the Gulf of Lion, which was partly cloud-free, on account of the strong Mistral jet blowing in the region. AODs at $865 \mathrm{~nm}$ could only be retrieved in the cloud-free part of the Gulf of Lion, but displays a minimum south of the city of Montpellier $\left(0.11\right.$ around $\left.4^{\circ} \mathrm{E}\right)$ and a maximum south of the Fos/Berre industrial area $\left(0.18\right.$ around $\left.4.7^{\circ} \mathrm{E}\right)$, along leg AF of the ARAT aircraft (Fig. 1) (west/east gradient). In the Mistral region (leg FC), the AOD at $865 \mathrm{~nm}$ varies from 0.17 around way-point $F$ (Fig. 1) to over 0.2 near the coast (Fos/Berre region and further east) along a south-north gradient. The aerosol distribution simulated by CHIMERE, using the recently developed methodology by Hodzic et al. (2004), can be compared to the AOD retrieved from SeaWIFS in the cloud-free regions. Figure $8 \mathrm{~b}$ shows the AOD at $865 \mathrm{~nm}$ simulated with CHIMERE over the domain documented by SeaWIFS. The location of the Marseille/Fos-Berre aerosol plume is reproduced by CHIMERE (shifted by about $20 \mathrm{~km}$ to the east, i.e. around $6^{\circ} \mathrm{E}$ ) with an AOD of about 0.16 , as well as the aerosol plume from the industrial city of Toulon. The plume emerging from the Aude valley channelling the Tramontane, as well as the plume skirting the eastern Spanish coast (Fig. 8a), are only partially visible in the SeaWIFS data because these regions are covered by clouds preventing reliable retrieval of aerosol products (Fig. 8b, c between 3.5 and $4^{\circ} \mathrm{E}$ ). Emission of sea salts occurs in localized areas which evolve during the day with respect to the evolving dynamics. High concentrations of sea salts are found 

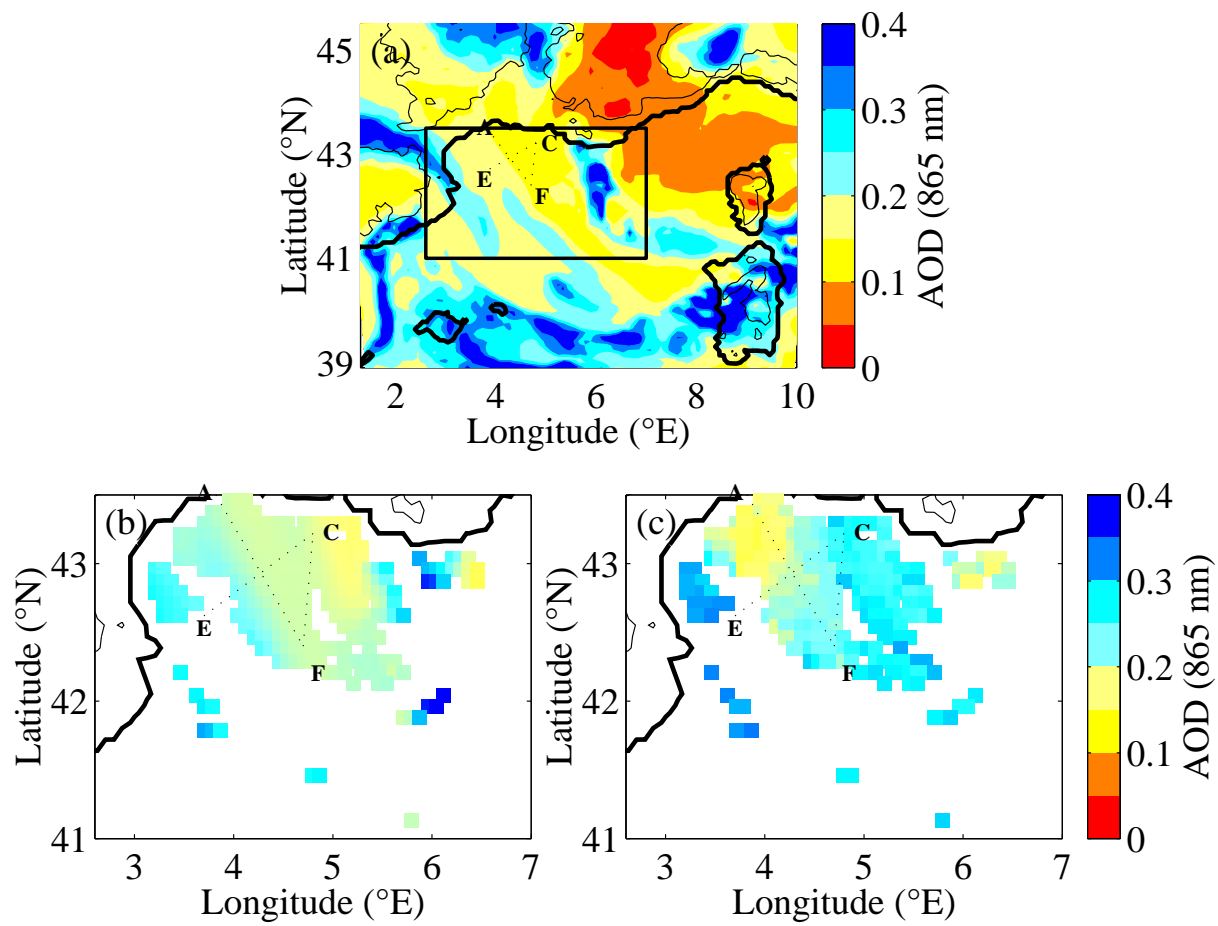

Fig. 8. Panel (a): simulated aerosol optical depth (AOD) at $865 \mathrm{~nm}$ derived from CHIMERE simulation at 12:00 UTC (domain 2). The rectangle indicates the zoomed area shown in panels (b) and (c); Panel (b): simulated AOD at $865 \mathrm{~nm}$ at 12:00 UTC over the Gulf of Lions with the cloud mask derived from the Sea-viewing Wide Field-of-view Sensor (SeaWIFS) observations; Panel (c): AOD at 865 nm derived from SeaWIFS measurements at 11:32 UTC. The dotted line corresponds to the flight track of the ARAT carrying the water vapor lidar LEANDRE-2 on 24 March 1998 in the afternoon.

in intense wind regions, where the Mistral and Tramontane blow, but conversely low values are also found where the Ligurian outflow strengthens between 12:00 and 15:00 UTC. On average, in the regions where suspension of sea salts occurs, the contribution of the sea salts to the overall aerosol loading ranges between 1\% (over the Ligurian Sea) and 10\% (to the west of Sardinia). The contribution of sea-salt particles to the total AOD ranges from 1 to $10 \%$ (see Fig. 9). These results are consistent with values reported in recent papers by Collins et al. (2002) or Halthore and Caffrey (2006) for various open-sea locations. On average, the simulated AOD is in good agreement with the SeaWIFS observations but in some plumes, the simulated AOD can be $30 \%$ smaller than the observed AOD (due to AOD retrieval from the data, the slight shift in the plume locations, and also due to Hanel's relation used to compute the water uptake by the sea salts as a function of relative humidity).

In the afternoon of 24 March 1998, the vertical structure of the aerosols, as well as the ABL, were documented by the lidar LEANDRE-2 along legs AF, FC and CE (Fig. 10), as detailed by Flamant (2003). Lidar measurements on leg AF (Fig. 10b) show an internal boundary layer developing from the coast (within the advected continental $\mathrm{ABL}$ ) and reaching a depth of $1200 \mathrm{~m}$. Close to way-point $\mathrm{F}$, at approximately $42.6^{\circ} \mathrm{N}$, the marine $\mathrm{ABL}$ structure character-

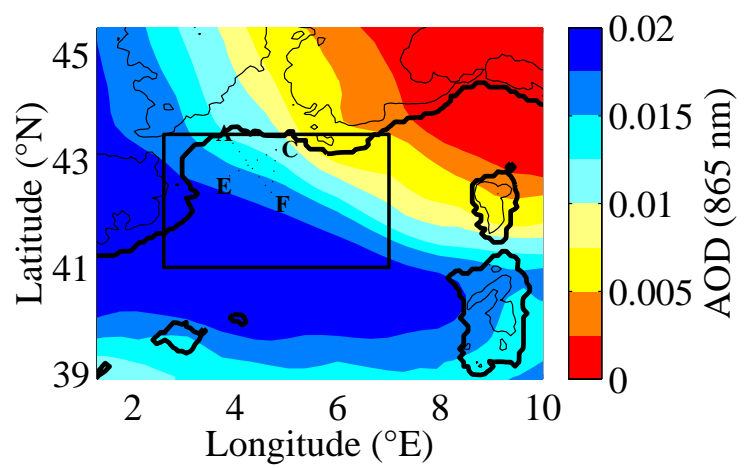

Fig. 9. Simulated sea-salt optical depth (AOD) at $865 \mathrm{~nm}$ derived from CHIMERE simulation at 12:00 UTC (domain 2). The dotted line corresponds to the flight track of the ARAT carrying the water vapor lidar LEANDRE-2 on 24 March 1998 in the afternoon.

istics over the sea changed: it is observed to be shallower (700 $\mathrm{m}$ in Fig. 10b) and is characterized by larger values of atmospheric reflectivity. This is confirmed by measurements made on leg FC (Fig. 10d), along which the marine ABL is characterized by values of atmospheric reflectivity similar to those observed near way-point $\mathrm{F}(700 \mathrm{~m})$. Also, the marine $\mathrm{ABL}$ is observed to remain shallow, its depth gradually 

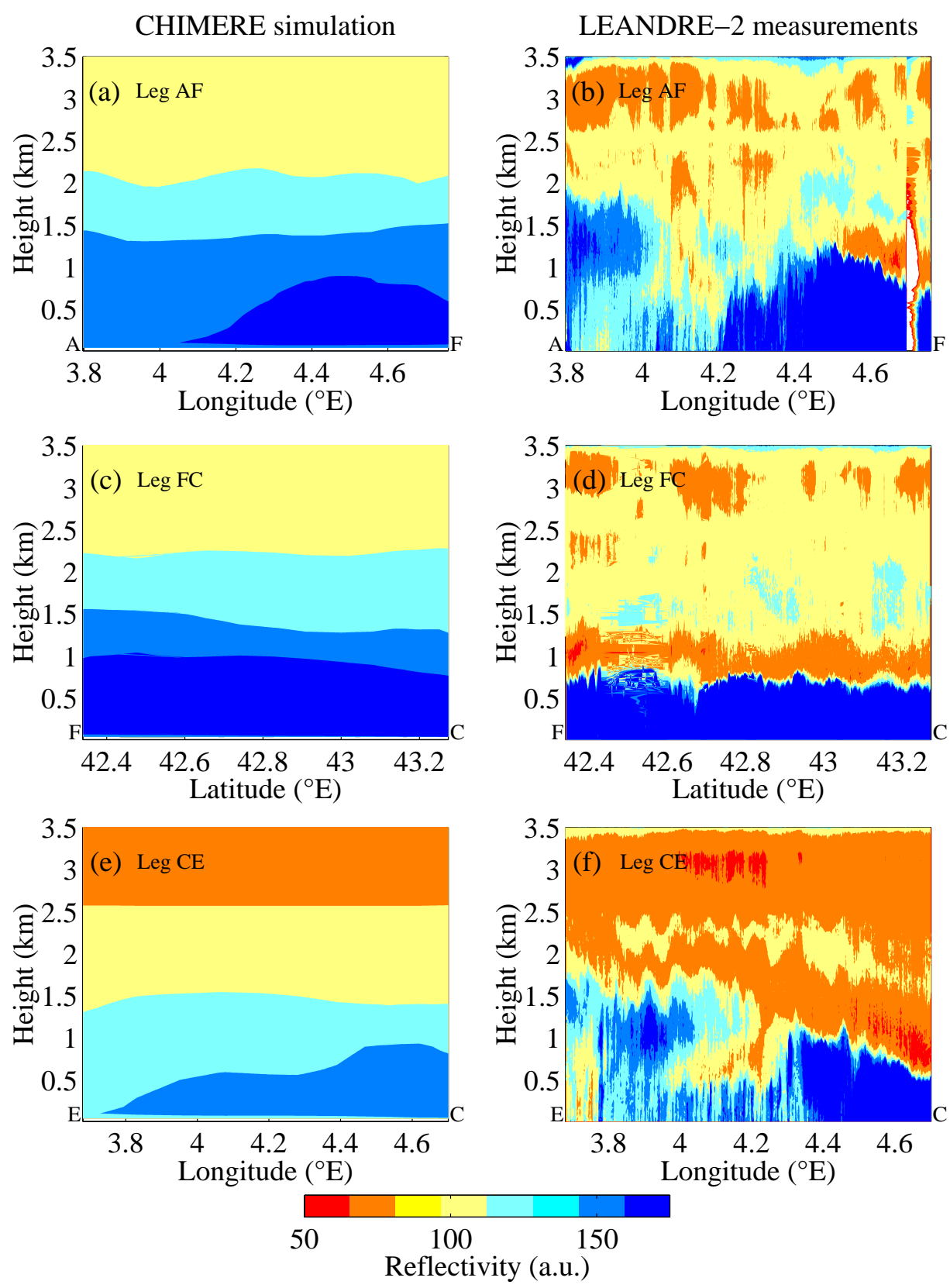

Fig. 10. Atmospheric reflectivity at $0.73 \mathrm{~nm}$ as obtained from LEANDRE-2 (right column) and CHIMERE (left column) along leg CE (a and b), leg FC (c and d), and leg AF (e and f) on the afternoon of 24 March 1998. Way points A, C, and E are shown in Fig. 1c. The aerosolladden marine $\mathrm{ABL}$ is characterized by high reflectivity values, while the advected continental ABL exhibits reflectivity values comprised between 80 and 1200 a.u. The free troposphere above the ABL is characterized by a reflectivity value of 80 a.u. or less. At the bottom of all panels, the ending and starting way points are indicated.

increasing from 500 to $700 \mathrm{~m}$ with the distance to the coast (leg FC, Fig. 10d). As discussed in Flamant (2003), the larger atmospheric reflectivity values in the eastern part of the sampled region (leg FC) is thought to be related to larger concentrations of pollution aerosol from the city of Marseille and the industrial petrochemical complex of Fos/Berre. On leg CE (Fig. 10f), close to the coast (near way-point C), the
ABL structure is similar to that observed along FC (i.e. shallow). The depth of the ABL increases westward from 500 to $1200 \mathrm{~m}$ with reflectivity values on the order of those observed on leg AF. Further to the west, a continental ABL is observed in the sheltered region in the lee of the Massif Central, with reflectivity values being significantly smaller than to the east of $43^{\circ} \mathrm{N}$. In this region, on leg CE, lidar measurements 

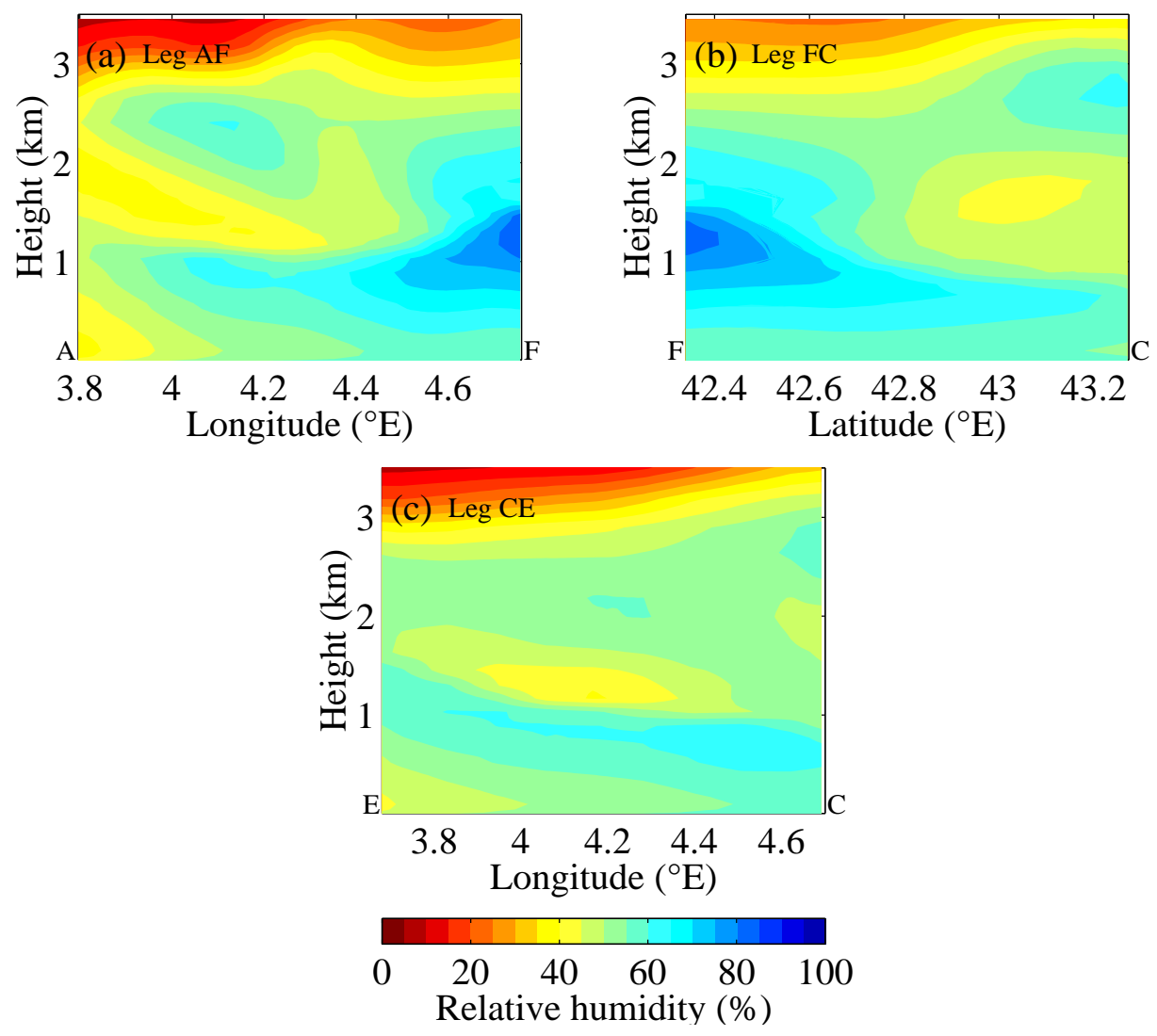

Fig. 11. Vertical profiles of relative humidity simulated with MM5 and extracted from domain 2 along legs AF (a), CE (b) and FC (c). At the bottom of all panels, the ending and starting way points are indicated.

evidence the presence of gravity waves (at $2.2 \mathrm{~km}$ ) inside the continental $\mathrm{ABL}$ and above, which are common features during Mistral events (Caccia et al., 2004; Drobinski et al., 2005). The vertical structure of the aerosol distribution in the atmosphere derived from LEANDRE-2 reflectivity is used to validate the CHIMERE simulations along the ARAT legs. We use the methodology by Hodzic et al. (2004) that consists of simulating the lidar backscattering profiles from the model relative humidity and concentration outputs (optical properties varying with chemical composition and mass vertical distribution). Figures 10 and 11 show the simulated lidar reflectivity and relative humidity along legs AF, CE and FC. To obtain a quantitative comparison between the measured and simulated reflectivities, the simulated lidar profiles are normalized by the measured values in the aerosol-free layer (at about $3.8 \mathrm{~km}$ in the troposphere). Figure 11 shows the relative humidity field which displays a west (relative humidity of about $40 \%$ )-east (relative humidity of about $60 \%$ ) gradient. When the relative humidity increases from 40 to $60 \%$, aerosol uptakes more water (deliquescence region) and therefore the aerosol distribution changes and also its total mass also changes (mass of water increases). So, this can affect the lidar signal, especially with the sea salts. A sensi- tivity study was thus performed which consisted of computing the lidar reflectivity with homogeneous relative humidity along the legs (60\% and 40\%) (not shown). It showed that the overall structure of the lidar reflectivity is not affected by the relative humidity. The variability along the legs still stands with homogeneous relative humidity. The gradient of relative humidity along the leg thus plays a minor role (less than $1 \%$ due to the hygroscopicity of the sea salts). The lidar reflectivity can thus be directly related to the aerosol concentration without any modulation of the aerosol size by the hygroscopic effect.

Despite some differences in the lidar reflectivity field, the simulation displays many similar features. The main difference is the thin aerosol-free layer (reflectivity values of about 50 a.u.) just above the $\mathrm{ABL}$ (reflectivity values larger than 150 a.u.) which is not reproduced by CHIMERE. Otherwise, the second layer above the ABL (the advected continental ABL with reflectivity values of about 100-120 a.u.) is accurately simulated for all legs. The transition between the marine $\mathrm{ABL}$ and the advected continental $\mathrm{ABL}$ is thus too smooth in the simulation, probably because of a diffusivity that is too large, which prevents the model from predicting this aerosol-free layer between the marine ABL and 

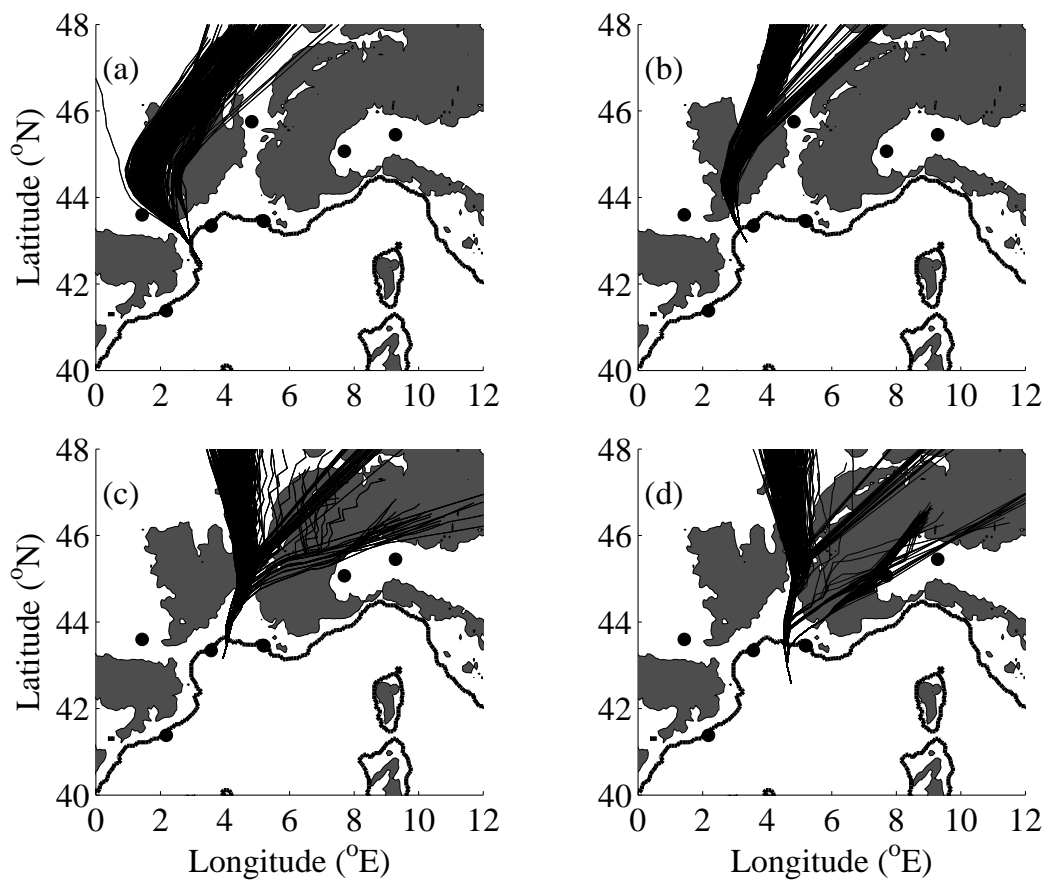

Fig. 12. Back plumes ending at $3.3^{\circ} \mathrm{E} / 42.5^{\circ} \mathrm{N}$ (a), $3.39^{\circ} \mathrm{E} / 43^{\circ} \mathrm{N}(\mathbf{b}), 3.95^{\circ} \mathrm{E} / 43.16^{\circ} \mathrm{N}$ (c) and $4.75^{\circ} \mathrm{E} / 42.6^{\circ} \mathrm{N}$ (d) (shown in Fig. 8). The altitude of the ending points is $50 \mathrm{~m}$. The ending time of the back plumes is 11:00 UTC which is the time of the passage of SeaWIFS over the western Mediterranean. The wind fields used to compute these back plumes are from the 9-km mesh size domain. Filled black dots indicate the cities of Barcelona, Toulouse, Montpellier, Marseille/Fos-Berre, Lyon, Torino and Milano.

the advected continental ABL. It can also be due to a slight mismatch in the wind field which does not bring this aerosolfree air mass to the right place. The study of the dynamics of such thin layers is out of the scope of this study and is left for future work. Along leg FC, the aerosol backscatter is homogeneous in the ABL, both in the observations and the simulation, since the aircraft flies along the aerosol plume (Fig. 8), with a very weak deepening of the ABL, from east to west (the CHIMERE simulation, however, overpredicts by about $200 \mathrm{~m}$ the ABL depth west of leg FC). Along legs CE and $\mathrm{AF}$, the aerosol backscatter in the $\mathrm{ABL}$ varies along the legs, with larger reflectivity on the eastern part of the leg. However, the location of the aerosol plume is accurately reproduced with an aerosol core at about $1 \mathrm{~km}$ height, between 3.8 and $4.0^{\circ} \mathrm{E}$ in the LEANDRE-2 observations. West of $3.8^{\circ} \mathrm{E}$, the aerosol content decreases. Along leg AF, the model accurately reproduces the heavily loaded aerosol plumes east of $4.2^{\circ}$ E. Between 3.8 and $4.2^{\circ} \mathrm{E}$, the CHIMERE model simulates the incursion of a low aerosol streak within the ABL, but is not able to reproduce its fine-scale structure and the simulated reflectivity is larger than the measured reflectivity.

To assess the air masses responsible for the aerosol variability in ABL, in the Gulf of Lion area, we computed back plumes ending at various locations in the aerosol plume documented by SeaWIFS (Fig. 12) and LEANDRE-2 (Figs. 13 and 14), using a lagrangian particle dispersion model (Menut et al., 2000) and the MM5 wind fields. During the convective period, air parcels are mixed within the ABL. Hence, neither constant-altitude back plumes nor back plumes following the mean three-dimensional wind would be realistic. In order to overcome this problem, air trajectories are assumed to undergo a random altitude change every hour during the convective period. They were nevertheless bounded to stay between 0 and $1000 \mathrm{~m}$ (tests with the upper boundary of 2000 and $3000 \mathrm{~m}$ have been conducted without any impact). Fifty back plumes are calculated in this way (due to convection, an ending point does not correspond to the same air mass origin, so 50 back plumes are computed in order to quantify the scatter of the air mass origin locations). Figure 12 (a and b) shows that the air masses following similar trajectories and ending on the western edge of the aerosol plume at 11:00 UTC can be clustered in two groups: one cluster follows the Aude valley channelling the Tramontane flow, the other follows the western boundary of the Mistral flow. There are no major urban and industrial aerosol sources along the two trajectories, except maybe the cities of Toulouse and Montpellier (Figs. 1b and 7). Figure 12 (c and d) shows that the center and eastern regions of the aerosol plume originate from the Marseille/Fos-Berre area but also from further sources. To the north, emissions from Lyon are transported by the Mistral (see also Corsmeier et al., 2005, for a summer Mistral) and to the east, a cross-Alpine flow carries the 

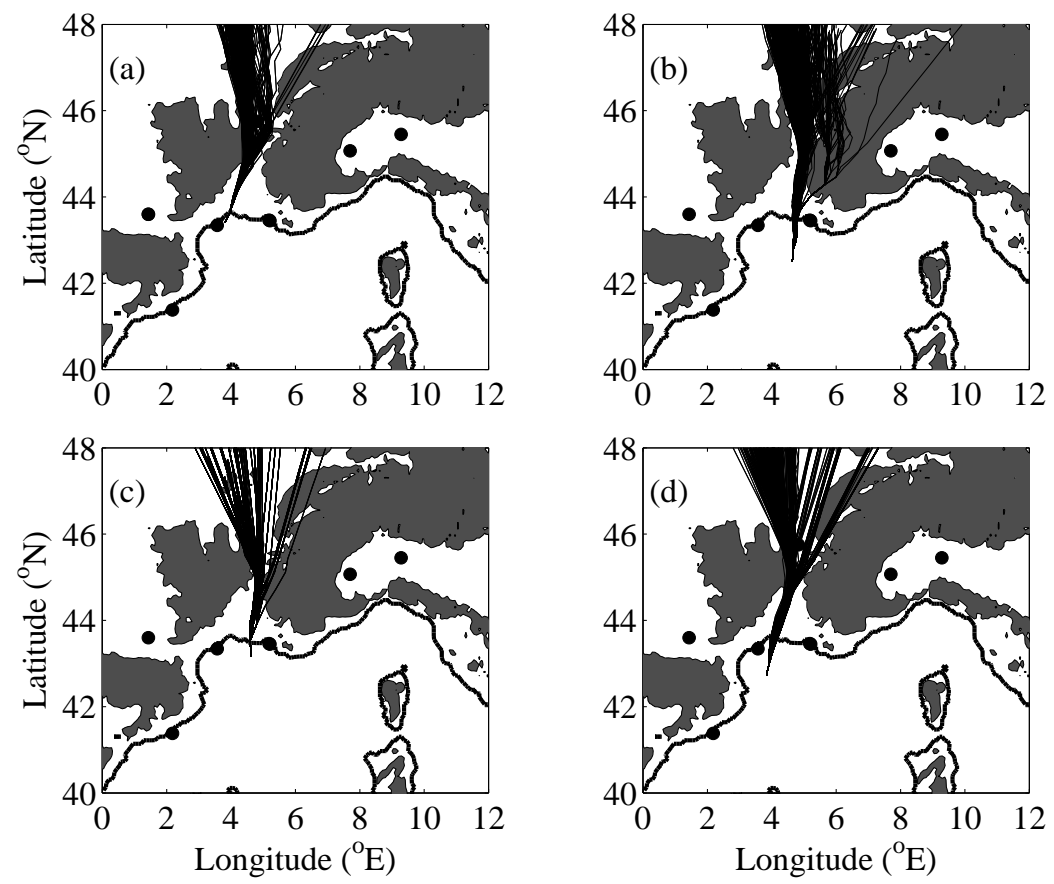

Fig. 13. Back plumes ending at $3.9^{\circ} \mathrm{E} / 43.4^{\circ} \mathrm{N}$ (way-point A) (a), $4.65^{\circ} \mathrm{E} / 42.5^{\circ} \mathrm{N}$ (way-point $\mathrm{F}$ ) (b), $4.7^{\circ} \mathrm{E} / 43.2^{\circ} \mathrm{N}$ (way-point $\mathrm{C}$ ) (c) and $3.88^{\circ} \mathrm{E} / 42.75^{\circ} \mathrm{N}$ (way-point $\mathrm{E}$ ) (d). The back plumes ending points correspond to the starting and ending points of the ARAT legs and the aerosol plumes detected by the lidar LEANDRE-2 on board the ARAT. The altitude of the ending points is $50 \mathrm{~m}$. The ending times of the back plumes are 16:00 and 17:00 UTC for the first and second rows, respectively. Filled black dots indicate the cities of Barcelona, Toulouse, Montpellier, Marseille/Fos-Berre, Lyon, Torino and Milano.
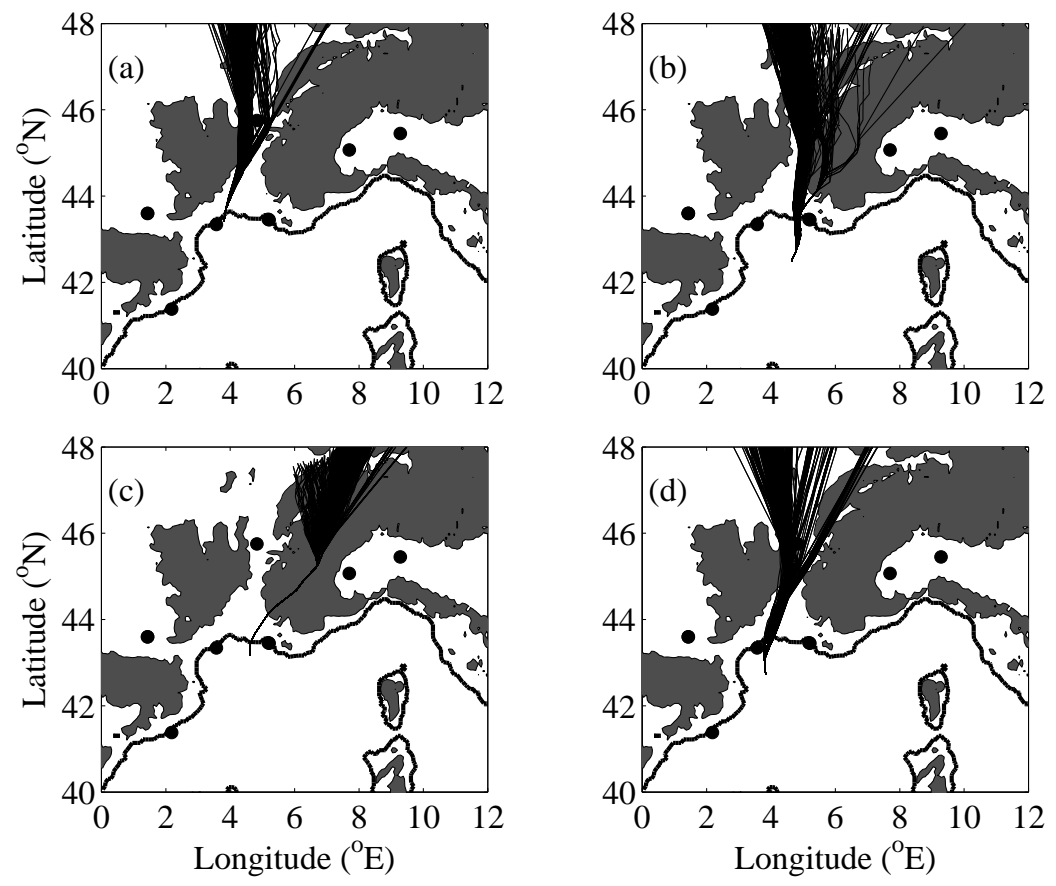

Fig. 14. Same as Fig. 13 but for back plumes ending at $2000 \mathrm{~m}$ m.s.1. 

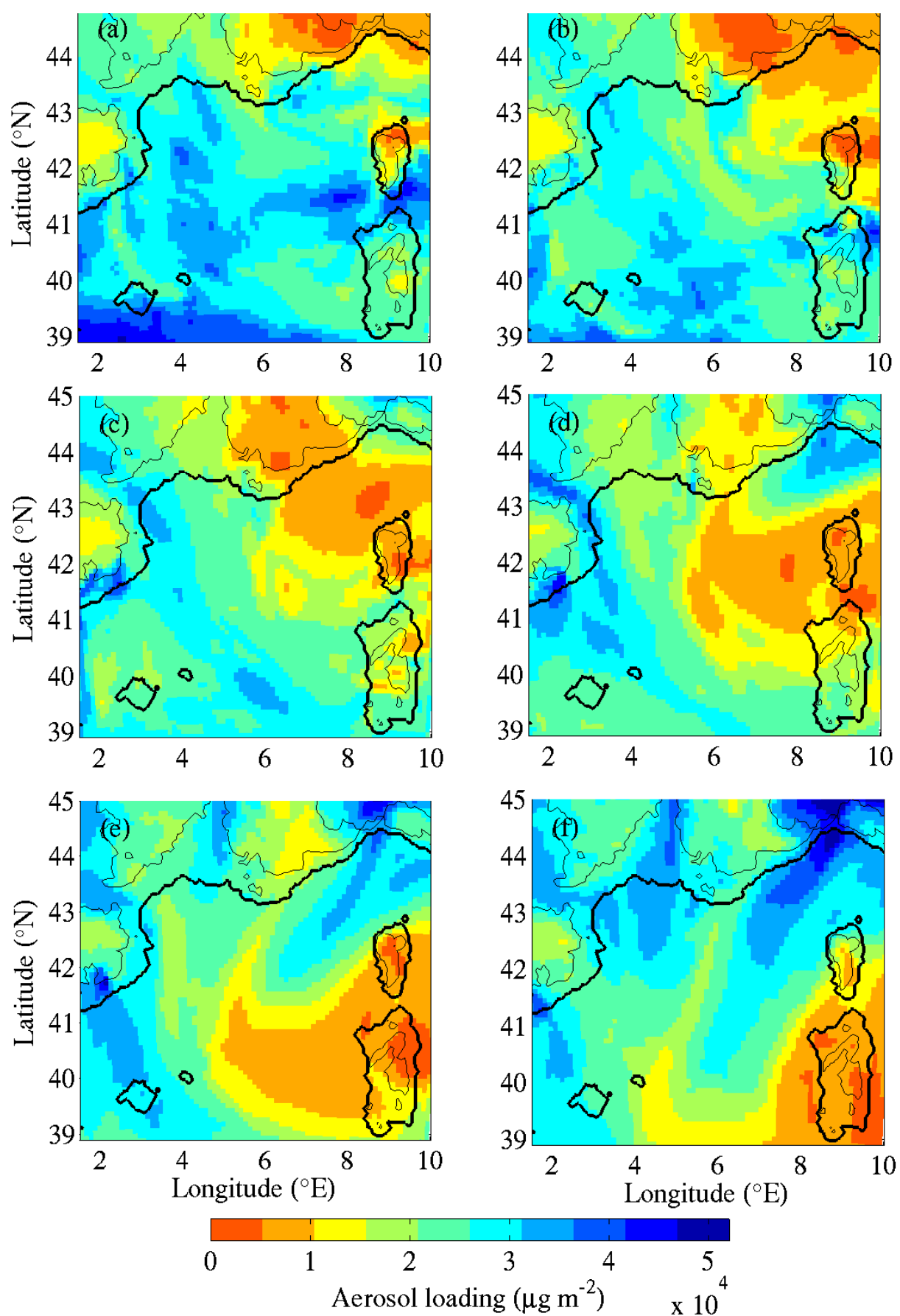

Fig. 15. Aerosol loading over the western Mediterranean basin. Panels (a), (b), (c) and (d) display the particulate concentrations fields modelled with CHIMERE on domain 2 at 06:00, 09:00, 12:00, 15:00, 18:00 and 21:00 UTC, respectively. Solid lines represent the coastlines and elevations beyond $500 \mathrm{~m}$.

emissions from the heavily industrialized regions of the Po Valley in Italy. The regions of Marseille/Fos-Berre, Lyon and Torino are major emission sources compared to Toulouse or Montpellier, thus explaining why the western region of the plume is optically thinner than the middle and eastern regions of the plume.
The back plumes ending along the ARAT legs at two different altitudes $(50 \mathrm{~m}$ within the ABL, $2000 \mathrm{~m}$ within the advected aerosol-rich continental ABL above the marine ABL) also explain the differences in aerosol concentration observed by LEANDRE-2. At $50 \mathrm{~m}$ (and higher within the ABL, not shown), large-scale transport from Lyon is visible 
on the four clusters of back plumes. However, at ending points $\mathrm{A}$ and $\mathrm{E}$, the air masses do not flow over the Marseille/Fos-Berre area or other major cities, explaining the lower aerosol content observed by LEANDRE-2 within the marine ABL. On the contrary, the air masses ending at points $\mathrm{C}$ and $\mathrm{F}$ are enriched in aerosols as they pass over the Marseille/Fos-Berre area, explaining the higher reflectivity values in the ABL. Along leg FC, the ARAT follows the Marseille/Fos-Berre plume, explaining the homogeneous concentration of aerosols along the leg.

At $2000 \mathrm{~m}$, the aerosols of the layer just above the marine $\mathrm{ABL}$ (reflectivity values of about 100 a.u.) originate from remote sources (e.g. Lyon) which are then transported over a long range (Corsemeier et al., 2005) (Fig. 14 similar to Fig. 13). One exception is at ending point $C$ which is just above this aerosol-rich layer, in the aerosol-free layer (Fig. 10). Figure 14c shows that the air mass flows over the advected continental ABL above the western Alps and originates from the northern Alps. The absence of significant aerosol sources in this area explains the very low reflectivity values at $2000 \mathrm{~m}$ at ending point $\mathrm{C}$. One can finally notice the absence of trans-alpine transport between 16:00 and 17:00 UTC, contrary to the situation at 11:00 UTC. This is the result of an evolution of the regime of the flow impinging on the Alpine ridge: at 11:00 UTC, part of the upstream air mass flows over the mountain, whereas at 16:00 and 17:00 UTC, the air mass is mostly blocked by the Alps and flows around. In Fig. 2, it is illustrated by the larger extension of the western Alpine wake in the afternoon.

\subsection{Aerosol distribution over the western Mediterranean from the MM5-CHIMERE model}

Insight into the aerosol distribution, origin and composition over the western Mediterranean can be obtained from the CHIMERE aerosol products, in close relationship with the mesoscale dynamical processes accessible from the validated MM5 meteorological fields. In the following, the aerosol distribution, origin and composition will be discussed as a function of the position and intensity of the "eye" of the Genoa cyclone on 24 March.

During the morning period, the Genoa cyclone is located immediately to the east of Corsica, the surface pressure low gradually decreasing from 1014 to $1010 \mathrm{hPa}$. Over the southwestern region of the Mediterranean basin, large aerosol loading can be attributed to ship emissions (see Figs. 7 and $15 \mathrm{a}$ and $\mathrm{b}$ ). South of Sardinia, the air circulating around the Genoa surface low brings ship emissions to southern Italy. North of this band, most of the aerosol loading over the Mediterranean Sea is of local origin (intercontinental ship tracks and coastal urban and industrialized area, such as Barcelona, Marseille/Fos-Berre, Toulon; see Fig. 7 and Fig. 15a and $\mathrm{b}$ ), with one exception along the Aude valley, where the Tramontane transports offshore continental aerosols. The plume over Toulon stagnates in the western

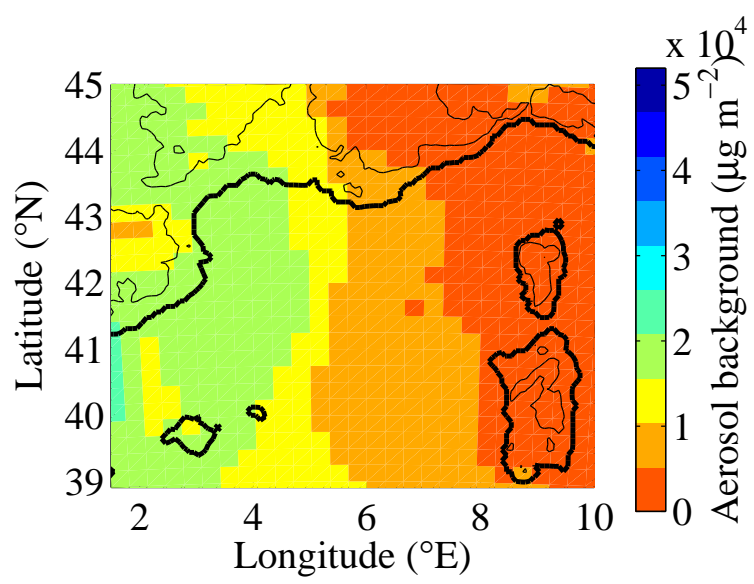

Fig. 16. Background aerosol loading in in $\mu \mathrm{g} \mathrm{m}^{-3}$ from the CHIMERE simulation.

Alps wake trailing downstream across the Alps, an area of very weak wind. Finally, the close location of the Genoa cyclone from Corsica and the absence of strong winds during the morning period lead to the fact that the region north and northwest of Corsica is only influenced by marine clean air.

During the afternoon period, the Genoa cyclone intensifies (from 1010 to $1004 \mathrm{hPa}$ ) and moves southeastward, about $300 \mathrm{~km}$ east of Sardinia over the Tyrrhenian Sea. The Tramontane has nearly vanished, so that the polluted air of the morning stagnates in the Aude valley. Conversely, the Mistral has intensified and most of the aerosols exported offshore originate from central France and the Marseille/FosBerre plumes. Moreover, the Ligurian outflow brings in the aerosols emitted from the major industrialized Italian cities (Milano and Torino) over the western part of the Mediterranean basin. This is consistent with aerosol optical depth values of 0.1 and 0.3 at 870 and $440 \mathrm{~nm}$, respectively, measured at Ispra (Italy) with the photometer of the AERONET network and with spectral distribution revealing high accumulation mode aerosol concentration. The CHIMERE AOD at $865 \mathrm{~nm}$ at Ispra is about 0.09 , in very good agreement with the actual value. A narrow band of clean air separates the two major plumes extending more than $300 \mathrm{~km}$ over the sea. This cleaner air corresponds to the western Alps wake and, associated with a large horizontal shear of wind, acts as a dynamical barrier, preventing any lateral exchanges between the Mistral and the Ligurian outflow. The southeastward displacement and intensification of the Genoa cyclone increases the meridian extension of the Mistral that sweeps away the band of aerosols emitted from the ships that skirt the North African coast in the morning (Fig. 15c and d). All day long, sea salts are put into suspension in the region of strong winds but their contribution to the overall aerosol loading ranges between 1 and $10 \%$ only (not shown).

We now evaluate the amount of aerosol mass transported by the Mistral, Tramontane and the Ligurian outflow, in 

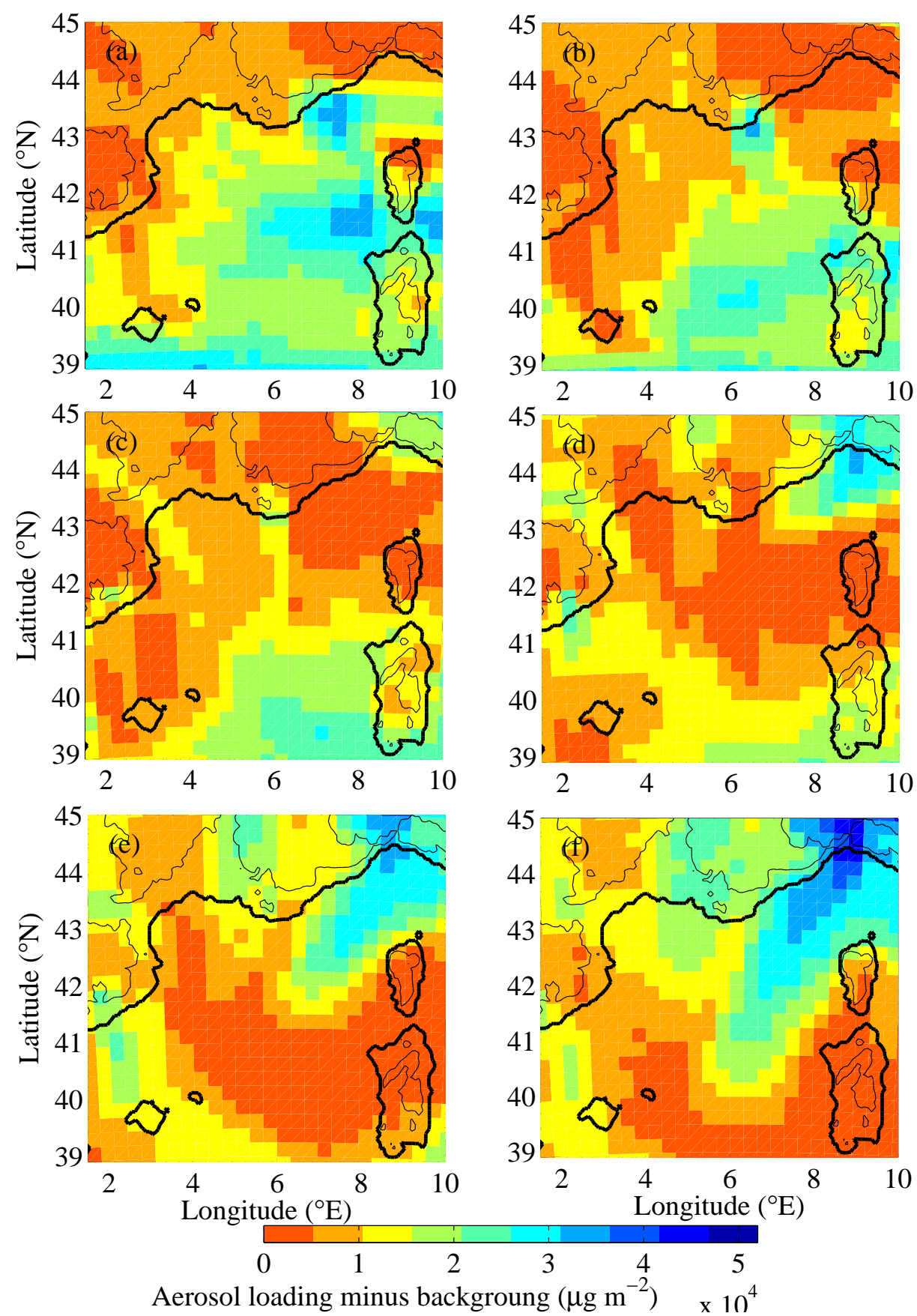

Fig. 17. Amount of aerosol in $\mu \mathrm{g} \mathrm{m}^{-3}$ transported by the Mistral, Tramontane and Ligurian outflow, in addition to the background aerosol loading (i.e. difference in the total aerosol loading minus the background aerosol loading). The panels correspond to 06:00, 09:00, 12:00, 15:00, 18:00, 21:00 UTC on 24 March 1998.

addition to the background aerosol mass. The background aerosol mass is computed from the CHIMERE simulations by taking the minimum value of the aerosol loading between 23 March and 25 March at every point of the simulation grid. The field of background aerosol loading is shown in Fig. 16. The amount of aerosol transported by the wind storms, in addition to the background aerosol loading, is thus the difference in the total aerosol loading minus the background aerosol loading and is shown in Fig. 17, which shows that the aerosols transported by the Mistral, Tramontane and Ligurian outflow are from marine origin and from the main industrial sources (Marseille/Fos-Berre; Po Valley). The amount 
of aerosol loading solely due to the strong winds is as large as 3-4 times the background aerosol amount. Measurements of nitrates available in the Netherlands and Italy evidence the development of an ammonium nitrate episode over western Europe on 24 March (not shown). These episodes are often observed in the late winter during such meteorological conditions, with a high pressure over Great Britain and central Europe (Bessagnet et al., 2005). The large nitrogen oxide emissions produce a large amount of nitric acid by oxidation, which is then neutralized by ammonia emitted in the same regions to form ammonium nitrate in the particulate phase, which compose part of the aerosol plume which we document and simulate in the region investigated in this paper.

\section{Conclusions}

Finally, this article presents a first attempt to characterize the aerosol distribution over the western Mediterranean basin during a Mistral event from the combination of innovative instrumentation (passive and active remote sensors) and the aerosol products of the fine-scale chemistry transport model CHIMERE, forced with the non-hydrostatic mesoscale model MM5. This issue is motivated by (1) the potential impact of aerosols on the Mediterranean radiative budget, the water cycle (through the modulation of precipitations) and the marine ecosystems; and (2) the very frequent occurrence of Mistral-type weather regimes ( 5 to 15 days per month, all year long, the longer duration being found in winter), thus making this case a representative case of the western Mediterranean climate. After validating the dynamical and chemical simulations, this paper shows that:

1. the Mistral contributes to export far offshore a large amount of aerosols emitted over continental Europe (in particular, ammonium nitrate in the particulate phase and sulfates) and along the shore from the industrialized and urban areas of Fos-Berre/Marseille, as well as from the Po Valley. This paper shows that the amount of aerosol loading solely due to the Mistral, Tramontane and Ligurian outflow is as large as 3-4 times the background aerosol amount and that the contribution of sea-salt particles to the total aerosol loading and optical depth ranges from 1 to $10 \%$, which are values consistent with those reported in the AEROCOM project ${ }^{1}$ and in recent published articles.

2. due to the time evolution of the Genoa cyclone position, the aerosol concentration pattern is very unsteady, as the Tramontane prevails in the morning hours of 24 March, leaving a place for the Mistral and an unusually strong Ligurian outflow in the afternoon. The Genoa surface low contributes to advect the aerosols along a

\footnotetext{
${ }^{1}$ see http://dataipsl.ipsl.jussieu.fr/cgi-bin/AEROCOM/aerocom/
}

cyclonic trajectory which skirts the North African coast and reaches Italy. The wakes trailing downstream the Massif Central and the Alps prevent any horizontal diffusion of the aerosols and can, in some cases, contribute to aerosol stagnation.

Acknowledgements. This work was conducted at Service d'Aéronomie and Laboratoire de Météorologie Dynamique of the Institut Pierre Simon Laplace. The authors would like to thank T. Elias, G. Bergametti, S. Bastin and C. Moulin for fruitful discussion; J. L. Monge for technical support; M. C. Lanceau for help in collecting the referenced papers; and D. Hauser for the coordination of the experiment. This research has received funding from the Agence de l'Environnement et de la Maîtrise de l'Énergie (ADEME) and support from Météo-France that provided the data from the operational radiosoundings and meteorological surface stations.

Topical Editor F. D'Andrea thanks two anonymous referees for their help in evaluating this paper.

\section{References}

Bartoli, G., Migon, C., and Losno, R.: Atmospheric input of dissolved inorganic phosphorus and silicon to the coastal northwestern Mediterranean Sea: fluxes, variability and possible impact on phytoplankton dynamics, Deep-Sea Res. I, 52, 2005-2016, 2005.

Bastin, S., Drobinski, P., Guénard, V., Caccia, J. L., Campistron, B., Dabas, A. M., Delville, P., Reitebuch, O., and Werner, C.: On the interaction between sea-breeze, and summer Mistral at the exit of the Rhône valley, Mon. Weather Rev., 134, 1647-1668, 2006.

Benitez-Nelson, C.: The biogeochemical cycling of phosphorus in marine systems, Earth-Sci. Rev., 51, 109-135, 2000.

Bergametti, G., Remoudaki, E., Losno, R., Steiner, E., Chatenet, B., and Buat-Menard, P.: Source, transport and deposition of atmospheric phosphorus over the Northwestern Mediterranean, J. Atmos. Chem., 14, 501-513, 1992.

Bessagnet, B., Hodzic, A., Blanchard, O., Lattuati, M., Le Bihan, O., Marfaing H., and Rouil, L.: Origin of particulate matter pollution episodes in wintertime over the Paris Basin, Atmos. Environ., 39, 6159-6174, 2005.

Bessagnet, B., Hodzic, A., Vautard, R., Beekmann, M., Cheinet, S., Honore, C., Liousse, C., and Rouil, L.: Aerosol modeling with CHIMERE-First evaluation at continental scale, Atmos. Environ., 38, 2803-2817, 2004.

Béthoux, J. P.: Oxygen consumption, new production, vertical advection and environmental evolution in the Mediterranean Sea, Deep-Sea Res., 36, 769-781, 1989.

Béthoux, J. P., Morin, P., and Ruiz-Pino, D.: Temporal trends in nutrient ratios: chemical evidence of Mediterranean ecosystem changes driven by human activity, Deep-Sea Res. II, 49, 20072016, 2002.

Caccia, J. L., Guénard, V., Bénech, B., Campistron, B., and Drobinski, P.: Vertical velocity and turbulence aspects during Mistral events as observed by UHF wind profilers, Ann. Geophys., 22, 3927-3936, 2004, http://www.ann-geophys.net/22/3927/2004/.

Chiriaco, M., Vautard, R., Chepfer, H., Haeffelin, M., Wanherdrick, Y., Morille, Y., Protat, A., and Dudhia, J.: The ability of MM5 
to simulate ice clouds: systematic comparison between simulated and measured fluxes and lidar/radar profiles at SIRTA atmospheric observatory, Mon. Weather Rev., 134, 897-918, 2006. Collins, W. D., Rasch, P. J., Eaton, B. E., Fillmore, D. W., Kiehl, J. T., Beck, C. T., and Zender, C. S.: Simulation of aerosol distributions and radiative forcing for INDOEX: Regional climate impacts, J. Geophys. Res., 107(D19), 8028, doi:10.1029/2000JD000032, 2002.

Corsmeier, U., Behrendt, R., Drobinski, P., and Kottmeier, C.: The Mistral and its effect on air pollution transport and vertical mixing, Atmos. Res., 74, 275-302, 2005.

Drobinski, P., Saïd, F., Ancellet, G., Arteta, J., Augustin, P., Bastin, S., Brut, A., Caccia, J.L., Campistron, B., Cautenet, S., Colette, A., Coll, I., Cros, B., Corsmeier, U., Dabas, A., Delbarre, H., Dufour, A., Durand, P., Guénard, V., Hasel, M., Kalthoff, N., Kottmeier, C., Lemonsu, A., Lasri, F., Lohou, F., Masson, V., Menut, L., Moppert, C., Peuch, V. H., Puygrenier, V., Reitebuch, O., and Vautard, R.: Regional transport and dilution during high pollution episodes in southern France: Summary of findings from the ESCOMPTE experiment, J. Geophys. Res., 112(D13105), doi:10.1029/2006JD007494, 2007.

Drobinski, P., Bastin, S., Guénard, V., Caccia, J. L., Dabas, A.M., Delville, P., Protat, A., Reitebuch, O., and Werner, C.: Summer Mistral at the exit of the Rhône valley, Q. J. Roy. Meteor. Soc., 131, 353-375, 2005.

Drobinski, P., Flamant, C., Dusek, J., Flamant, P. H., and Pelon, J.: Observational evidence and modeling of an internal hydraulic jump at the atmospheric boundary-layer top during a Tramontane event, Bound.-Lay. Meteor., 98, 497-515, 2001.

Dudhia, J. A.: Nonhydrostatic version of the Penn State-NCAR mesoscale model: validation tests and simulation of an Atlantic cyclone and cold front, Mon. Weather Rev., 121, 1493-1513, 1993.

Flamant, C.: Alpine lee cyclogenesis influence on air-sea heat exchanges and marine atmospheric boundary layer thermodynamics over the western Mediterranean during a Tramontane/Mistral event, J. Geophys. Res., 108 (C2), 8057, doi:10.1029/2001JC001040, 2003.

Georgelin, M. and Richard, E.: Numerical simulation of flow diversion around the Pyrenées: a Tramontana case study, Mon. Weather Rev., 124, 687-700, 1996.

Grell, G. A.: Prognostic evaluation of assumptions used by cumulus parameterizations, Mon. Weather Rev., 121, 764-787, 1993.

Grell, G. A., Dudhia, J., and Stauffer, D. R.: A description of the fifth-generation Penn State/NCAR mesoscale model (MM5), NCAR Technical Note, NCAR/TN-398+STR, 122 pp., 1995.

Guerzoni, S., Chester, R., Dulac, F., Herut, B., Loÿe-Pilot, M. D., Measures, C., Mignon, C., Molinaroli, E., Moulin, C., Rossini, P., Saydam, C., Soudine, A., and Ziveri, P.: The role of atmospheric deposition in the biogeochemistry of the Mediterranean Sea, Progress in Oceanography, 44, 147-190, 1999.

Guieu, C., Bozec, Y., Blain, S., Ridame, C., Sarthou, G., and Leblond, N.: Impact of high Saharan dust inputs on dissolved iron concentrations in the Mediterranean Sea, Geophys. Res. Lett., 29(19), 1911, doi:10.1029/2001GL014454, 2002.

Guo, Y. R. and Chen, S.: Terrain and land use for the fifth-generation Penn State/NCAR mesoscale modeling system (MM5), NCAR Technical Note, NCAR/TN-397+IA, 114 pp., 1994.
Halthore, R. N. and Caffrey, P. F.: Measurement and modeling of background aerosols in remote marine atmospheres: Implications for sea salt flux, Geophys. Res. Lett., 33, L14819, doi:10.1029/2006GL026302, 2006.

Hauser, D., Branger, H., Bouffies-Cloché, S., Despiau, S., Drennan, W. M., Dupuis, H., Durand, P., Durrieu de Madron, X., Estournel, C., Eymard, L., Flamant, C., Graber, H. C., Guérin, C., Kahma, K., Lachaud, G., Lefèvre, M. P., Pelon, J., Pettersson, H., Piguet, B., Queffeulou, P., Tailliez, D., Tournadre J., and Weill, A.: The FETCH experiment: an overview, J. Geophys. Res., 108(C3), 8053, doi:10.1029/2001JC001202, 2003.

Hong, S. Y. and Pan, H. L.: Nonlocal boundary layer vertical diffusion in a medium-range forecast model, Mon. Weather Rev., 124, 2322-2339, 1996.

Hodzic, A., Madronich, S., Bohn, B., Massie, S., Menut, L., and Wiedinmyer, C.: Wildfire particulate matter in Europe during summer 2003: meso-scale modeling of smoke emissions, transport and radiative effects, Atmos. Chem. Phys., 7, 4043-4064, 2007, http://www.atmos-chem-phys.net/7/4043/2007/.

Hodzic, A., Chepfer, H., Vautard, R., Chazette, P., Beekmann, M., Bessagnet, B., Chatenet, B., Cuesta, J., Drobinski, P., Goloub, P., Haeffelin, M., and Morille, Y.: Comparison of aerosol chemistrytransport model simulations with lidar and sun-photometer observations at a site near Paris, J. Geophys. Res., 109, D23201, doi:10.1029/2004JD004735, 2004.

Jansá, A.: Distribution of the mistral: A satellite observation, Meteorol. Atmos. Phys., 36, 201-214, 1987.

Lelieveld, J., Berresheim, H., Borrmann, S., Crutzen, P. J., Dentener, F. J., Fischer, H., Feichter, J., Flatau, P. J., Heland, J., Holzinger, R., Korrmann, R., Lawrence, M. G., Levin, Z., Markowicz, K. M., Mihalopoulos, N., Minikin, A., Ramanathan, V., de Reus, M., Roelofs, G. J., Scheeren, H. A., Sciare, J., Schlager, H., Schultz, M., Siegmund, P., Steil, B., Stephanou, E. G., Stier, P., Traub, M., Warneke, C., Williams, J., and Ziereis, H.: Global air pollution crossroads over the Mediterranean, Science, 298, 794-799, 2002.

Marmer, E. and Langmann, B.: Impact of ship emissions on the Mediterranean summertime pollution and climate: A regional model study, Atmos. Environ., 39, 4659-4669, 2005.

Mayençon, R.: Météorologie pratique, Editions Maritimes D’outremer, 1982.

Menut, L., Vautard, R., Flamant, C., Abonnel, C., Beekmann, M., Chazette, P., Flamant, P. H., Gombert, D., Guédalia, D., Kley, D., Lefebvre, M. P., Lossec, B., Martin, D., Mégie, G., Perros, P., Sicard, M., and Toupance, G.: Measurements and modelling of atmospheric pollution over the Paris area: an overview of the ESQUIF project, Ann. Geophys., 18, 1467-1481, 2000, http://www.ann-geophys.net/18/1467/2000/.

Migon, C., Copin-Montégut, G., Elégant, L., and Morelli, J.: Etude de l'apport atmosphérique en sels nutritifs au milieu côtier méditerranéen et implications biogéochimiques, Oceanologica Acta, 12, 187-191, 1989.

Mlawer, E. J., Taubman, S. J., Brown, P. D., Iacono, M. J., and Clough, S. A.: Radiative transfer for inhomogeneous atmosphere: RRTM, a validated correlated-k model for the longwave, J. Geophys. Res., 102(D14), 16 663-16682, 1997.

Monahan, E. C., Spiel, D. E., and Davidson, K. L.: A model of marine aerosol generation via whitecaps and wave disruption in: 
Oceanic Whitecaps, edited by: Monahan, E. C., Mac Niocaill, G., Riedel, Norwell, MA, 167-174, 1986.

Moulin, C., Lambert, C. E., Dayan, U., Masson, V., Ramonet, M., Bousquet, P., Legrand, M., Balkanski, Y. J., Guelle, W., Marticorena, B., Bergametti, G., and Dulac, F.: Satellite climatology of African dust transport in Mediterranean atmosphere, J. Geophys. Res., 103, 137-144, 1998.

Moulin, C., Lambert, C. E., Dulac, F., and Dayan, U.: Control of atmospheric export of dust from North Africa by the North Atlantic Oscillation, Nature, 387, 691-694, 1997.

Orieux, A. and Pouget, E.: Le Mistral: Contribution à l'étude de ses aspects synoptiques et régionaux, Direction de la Météorologie, Monographie 5, 1984.

Pace, G., Meloni, D., and Di Sarra, A.: Forest fire aerosol over the Mediterranean basin during summer 2003, J. Geophys. Res., 110, D21202, doi:10.1029/2005JD005986, 2005.

Prospero, J. M., Barrett, K., Church, T., Dentener, F., Duce, R. A., Galloway, J. N., Levy II, H., Moody, J., and Quinn, P.: Atmospheric deposition of nutrients to the North Atlantic Basin, Biogeochemistry, 35, 27-73, 1996.

Reisner, J., Rasmussen, R. J., and Bruintjes, R. T.: Explicit forecasting of supercooled liquid water in winter storms using the MM5 mesoscale model, Q. J. Roy. Meteorol. Soc., 124, 1071-1107, 1998.

Schmidt, H., Derognat, C., Vautard, R., and Beekmann, M.: A comparison of simulated and observed ozone mixing ratios for the summer of 1998 in Western Europe, Atmos. Environ., 35, 62776297, 2001.

Schneider, J., Borrmann, S., Wollny, A. G., Bläsner, M., Mihalopoulos, N., Oikonomou, K., Sciare, J., Teller, A., Levin, Z., and Worsnop, D. R.: Online mass spectrometric aerosol measurements during the MINOS campaign (Crete, August 2001), Atmos. Chem. Phys., 4, 65-80, 2004,

http://www.atmos-chem-phys.net/4/65/2004/.
Sciare, J., Cachier, H., Oikonomou, K., Ausset, P., Sarda-Estève, R., and Mihalopoulos, N.: Characterization of carbonaceous aerosols during the MINOS campaign in Crete, July-August 2001: a multi-analytical approach, Atmos. Chem. Phys., 3, 1743-1757, 2003, http://www.atmos-chem-phys.net/3/1743/2003/.

Traub, M., Fischer, H., de Reus, M., Kormann, R., Heland, J., Ziereis, H., Schlager, H., Holzinger, R., Williams, J., Warneke, C., de Gouw, J., and Lelieveld, J.: Chemical characteristics assigned to trajectory clusters during the MINOS campaign, Atmos. Chem. Phys., 3, 459-468, 2003, http://www.atmos-chem-phys.net/3/459/2003/.

Troen, I. and Mahrt, L.: A simple model of the atmospheric boundary layer; sensitivity to surface evaporation, Bound.-Lay. Meteorol., 37, 129-148, 1986.

Vautard, R., Martin, D., Beekmann, M., Drobinski, P., Friedrich, R., Jaubertie, A., Kley, D., Lattuati, M., Moral, P., Neininger, B., and Theloke, J.: Paris emission inventory diagnostics from the ESQUIF airborne measurements and a chemistry-transport model, J. Geophys. Res., 108, 8564, doi:10.1029/2002JD002797, 2003.

Vautard, R., Beekmann, M., Roux, J., and Gombert, D.: Validation of a hybrid forecasting system for the ozone concentrations over the Paris area, Atmos. Environ., 35, 2449-2461, 2001.

Vestreng, V.: EMEP/MSC-W Technical report. Review and Revision. Emission data reported to CLRTAP. MSC-W Status Report 2003. EMEP/MSC-W Note 1/2003, ISSN 0804-2446, 2003. 